\title{
Tooth enamel microstructure in North American Phytosauria (Diapsida:Archosauriformes): Implications for biogeography and ecology of a Late Triassic clade of crocodylian-like predators
}

\author{
Devin K. Hoffman, Jess A. Miller-Camp, and Andrew B. Heckert
}

\begin{abstract}
Teeth can provide important insight into diet and evolution of extinct vertebrates. Tooth enamel microstructure records functional and phylogenetic signals beyond the gross morphology of the dentition. Here, we provide the first systematic sampling of phytosaur tooth enamel to address questions of intra- and interspecific variation, and thus taxonomic identification, biogeographic connectivity, and heterodonty. We sampled 23 phytosaur teeth from five localities throughout the American Southwest and one locality from the Newark Supergroup of North Carolina. These teeth probably represent five heterodont genera and are tentatively assigned to Angistorhinus, Smilosuchus, Machaeroprosopus, Redondasaurus, and "Rutiodon". We used scanning electron microscopy to examine their enamel microstructure from transverse, longitudinal, and tangential cross-sections. All sampled teeth are composed of columnar enamel ranging in thickness from 20 to $150 \mu \mathrm{m}$, typically $50-100 \mu \mathrm{m}$, across all genera. In phytosaurs from the western US, lines of incremental growth (LIGs) are rare, whereas in the Newark Supergroup phytosaur "Rutiodon", LIGs are abundant and welldeveloped. Although phytosaur tooth enamel microstructure is not useful for the taxonomic assignment of isolated teeth, it can be used to differentiate phytosaurs from different basins and lends support to the hypothesis that western and eastern North American phytosaurs are taxonomically distinct. The posterior blade-like teeth of heterodont phytosaurs are consistently composed of proportionately thicker enamel (10$14 \mu \mathrm{m}$ thicker than anterior teeth of comparable size in heterodont phytosaurs), implying a greater degree of force on these teeth during food processing. Combined with independent measures of diet, enamel microstructure can help refine dietary hypotheses during the Triassic archosauriform radiation.
\end{abstract}

Devin K. Hoffman. Department of Geosciences, 4044 Derring Hall, Virginia Tech, Blacksburg, Virginia 24061, USA. devinkh5@vt.edu

Jess A. Miller-Camp, Department of Earth and Atmospheric Sciences, Indiana University, Bloomington, Indiana, USA. jessmc@iu.edu

Andrew B. Heckert, Department of Geological \& Environmental Sciences, Appalachian State University, Boone, North Carolina, USA. heckertab@appstate.edu

Hoffman, Devin K., Miller-Camp, Jess A., and Heckert, Andrew B. 2021. Tooth enamel microstructure in North American Phytosauria (Diapsida:Archosauriformes): Implications for biogeography and ecology of a Late Triassic clade of crocodylian-like predators.

Palaeontologia Electronica, 24(3):a32. https://doi.org/10.26879/1162

palaeo-electronica.org/content/2021/3440-phytosaur-tooth-enamel

Copyright: October 2021 Society of Vertebrate Paleontology.

This is an open access article distributed under the terms of the Creative Commons Attribution License, which permits unrestricted use, distribution, and reproduction in any medium, provided the original author and source are credited.

creativecommons.org/licenses/by/4.0 
Keywords: archosauriform; phytosaur; Triassic; tooth enamel; microstructure

\section{INTRODUCTION}

Phytosaurs are an extinct clade of archosauriform diapsids from Upper Triassic strata in North America, Europe, Africa, India, Madagascar, and Brazil (Figure 1A), and were most recently comprehensively reviewed by Stocker and Butler (2013). Traditionally, phytosaurs were long identified as "thecodonts" (e.g., Owen, 1859; Colbert et al., 1947) and then, with the advent of cladistic analyses, were almost always recovered as an early diverging branch of pseudosuchian archosaurs within crown-group Archosauria (e.g., Parrish, 1993; Brochu, 2001; Weinbaum and Hungerbühler, 2007). However, Nesbitt (2011) recovered Phytosauria outside of crown Archosauria as the latest diverging clade of non-archosaurian Archosauriformes (Figure 1B). More recently, Ezcurra (2016) and Ezcurra and Butler (2018) have again recovered Phytosauria as crown archosaurs (Archosauria), as an early-diverging clade of Pseudosuchia. While this has implications for the interpretation of the possible ancestral state of Archosauria, it is clear that enamel microstructure is plastic across and within clades (e.g., Sander, 1999; Hwang 2005 ; 2010; 2011) so we do not advocate for a particular position for Phytosauria.

Phytosaurs strongly, albeit superficially, resemble modern crocodylians in being quadrupedal, semi-aquatic predators with elongate, roughly triangular heads with many teeth. Like many crocodylians, several genera of phytosaurs possess a heterodont dentition (=variation in shape and size along jaw), though in both crocodylians and phytosaurs heterodonty varies in degree (D'Amore et al., 2019) and is far less than in mammals. Given this similarity to crocodylians, most researchers have interpreted phytosaurs as semi-aquatic predators (e.g., Chatterjee, 1978; Hunt, 1989; Datta et al., 2020). Hunt (1989) made more explicit comparisons of phytosaur skull shapes to that of gharials, alligators, and crocodiles to propose that some taxa were piscivorous (convergent with gharials), others may have relied primarily on terrestrial tetrapods for food (larger, more robust skulls convergent with large crocodiles), and still others were generalists. Hunt (1989) termed these skulls gracile, dolichorostral, and brachyrostral for piscivorous, generalist, and terrestrial diets, respectively.
Interestingly, none of these hypotheses have been rigorously tested, though stomach contents of Parasuchus hislopi that include the allokotosaur Malerisaurus (Chatterjee, 1980) suggest Hunt's (1989) hypothesis that gracile forms were obligatory piscivorous is inaccurate (Chatterjee, 1978). Additionally, the degree of heterodont dentition within phytosaurs has been proposed to represent variable feeding behaviors (Hungerbühler, 2000; Datta et al., 2021). Those with a conical, homodont dentition are proposed to correlate to gracile skulls of presumably piscivorous phytosaurs (Hungerbühler, 2000).

The degree of heterodonty in phytosaurs is described using general shape of teeth, variation in tooth size, and position in the jaw (Hunt, 1989; Hungerbühler, 2000; Datta et al., 2021; Figure 2A). Hunt's (1989) classification of phytosaur teeth used morphological features to identify teeth by their relative position in the cranium and lower jaws. Hungerbühler et al. (2000) and Datta et al. (2021) identified broadly similar morphotypes, and located them in the upper jaw, but did not really address the similar nature of the lower jaw dentition. Because we sampled isolated teeth that cannot be readily ascribed to upper or lower dentitions, we use the terminology of Hunt (1989). Thus, the largest, most mesial teeth that occupy the anterior "bulb" of the premaxilla and dentary are termed caniniform (or type C) teeth (Figure 2A). The unserrated, conical "piercing" teeth through the mesial half of the premaxilla and dentary are type $U$ (for unserrated) (Figure 2A). Proportionately tall, straight teeth in the distal half of premaxilla that possess at least some denticles on their carinae (usually the distal carinae are serrated) are termed intermediate (or type I) (Figure 2A). Finally, the shorter, doubly-serrated, blade-like maxillary and posterior teeth are type $B$ (for blade) teeth (Figure 2A; Hunt, 1989; Hungerbühler, 2000). These heterodont teeth are proposed to be used for a carnivorous diet, and with a primary function of, respectively: grabbing, piercing, immobilizing, and slicing (Hungerbühler, 2000). Although recent phytosaur enamel microwear work did not find support for different teeth or taxa specializing in distinct food processing strategies, there were textural differences between the different tooth positions 
(A)

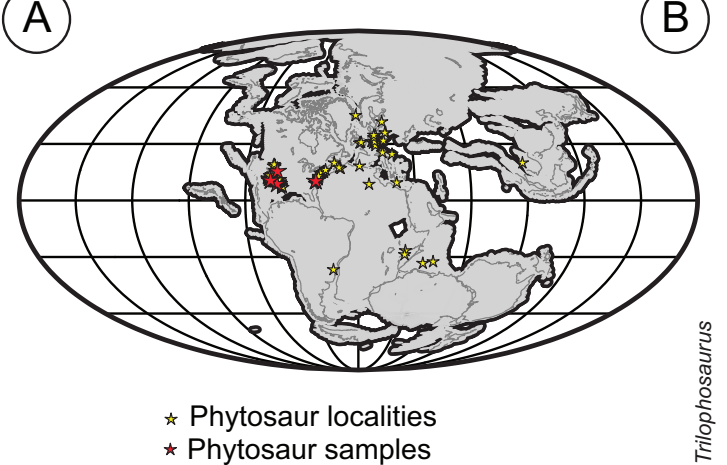

B)

* Phytosaur samples

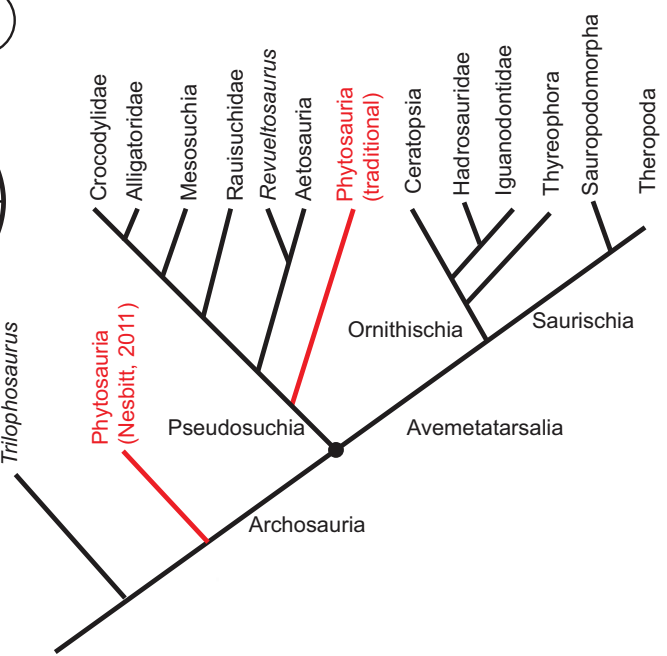

(C)

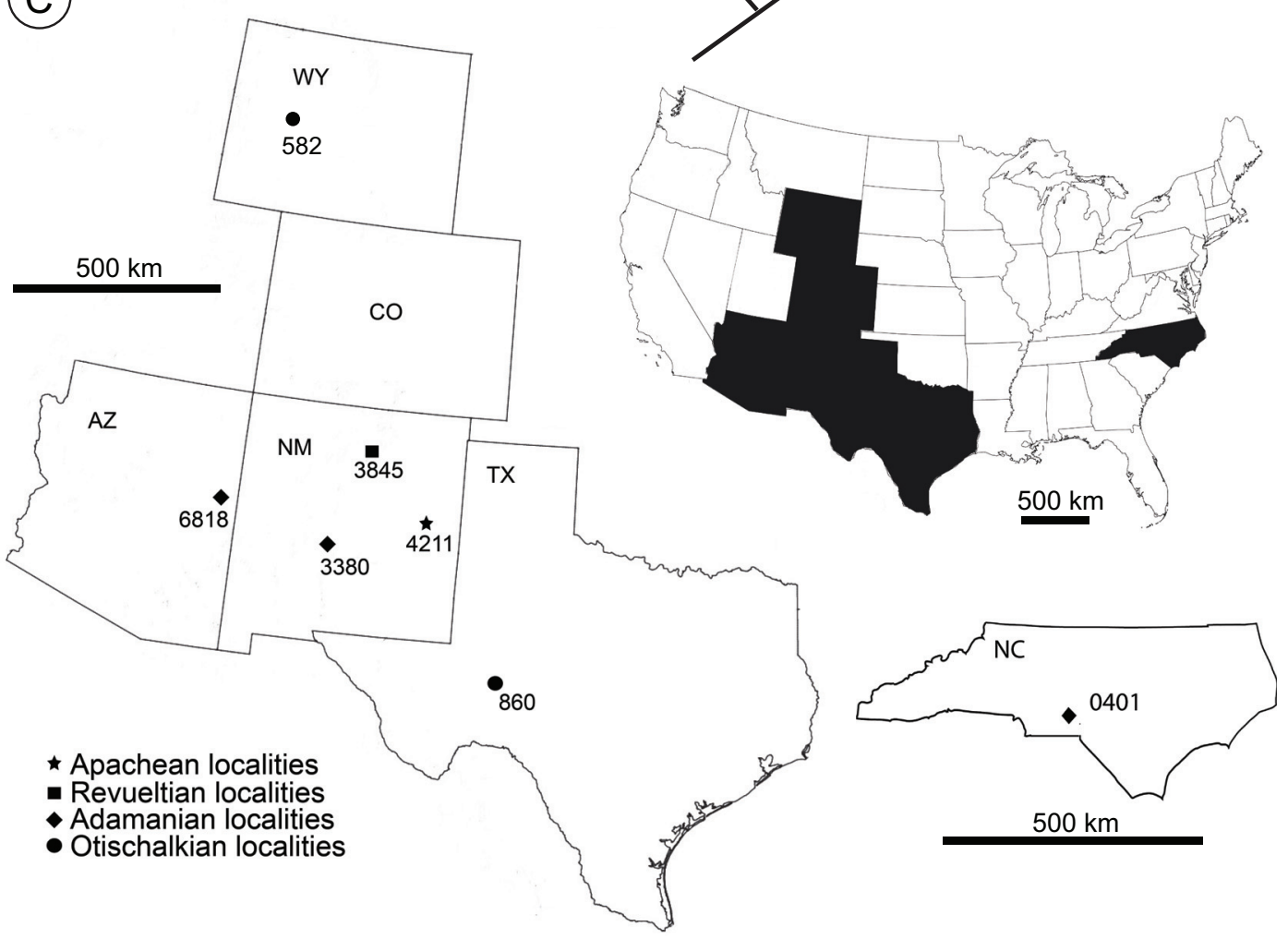

FIGURE 1. Geographic distribution and phylogenetic position of phytosaurs. 1A-Global distribution of phytosaur specimens from Middle and Late Triassic modified from Stocker and Butler (2013). Palaeomap from C. Scotese built into the Paleobiology Database for the Late Triassic (220 Ma) 1B-General cladogram of archosauromorphs that have been sampled for EM with the two possible positions of Phytosauria marked in red. Based on Heckert and Miller-Camp (2012) 1C-Locality map of specimens used in this study. North Carolina not to the same scale as western states. Locality numbers from NMMNH (western states) or NCSM (North Carolina).

along the jaw, indicating differential pressure loading (Bestwick et al., 2021).

The fossil record of phytosaurs consists primarily of isolated elements-articulated skeletons are extremely rare and even associated skeletons are uncommon (e.g., Chatterjee, 1978; Gozzi and Renesto, 2003). As a consequence, phytosaur tax- onomy has always relied heavily on skulls in both the pre-cladistic (e.g., McGregor, 1906; Huene, 1922; Camp, 1930; Gregory, 1962; Hunt, 1989; Long and Murry, 1995) and post-cladistic (Ballew, 1989; Hungerbühler, 2002; Stocker, 2010, 2012; Stocker and Butler, 2013; Kammerer et al. 2016; Jones and Butler, 2018; Datta et al. 2019) eras. 
A
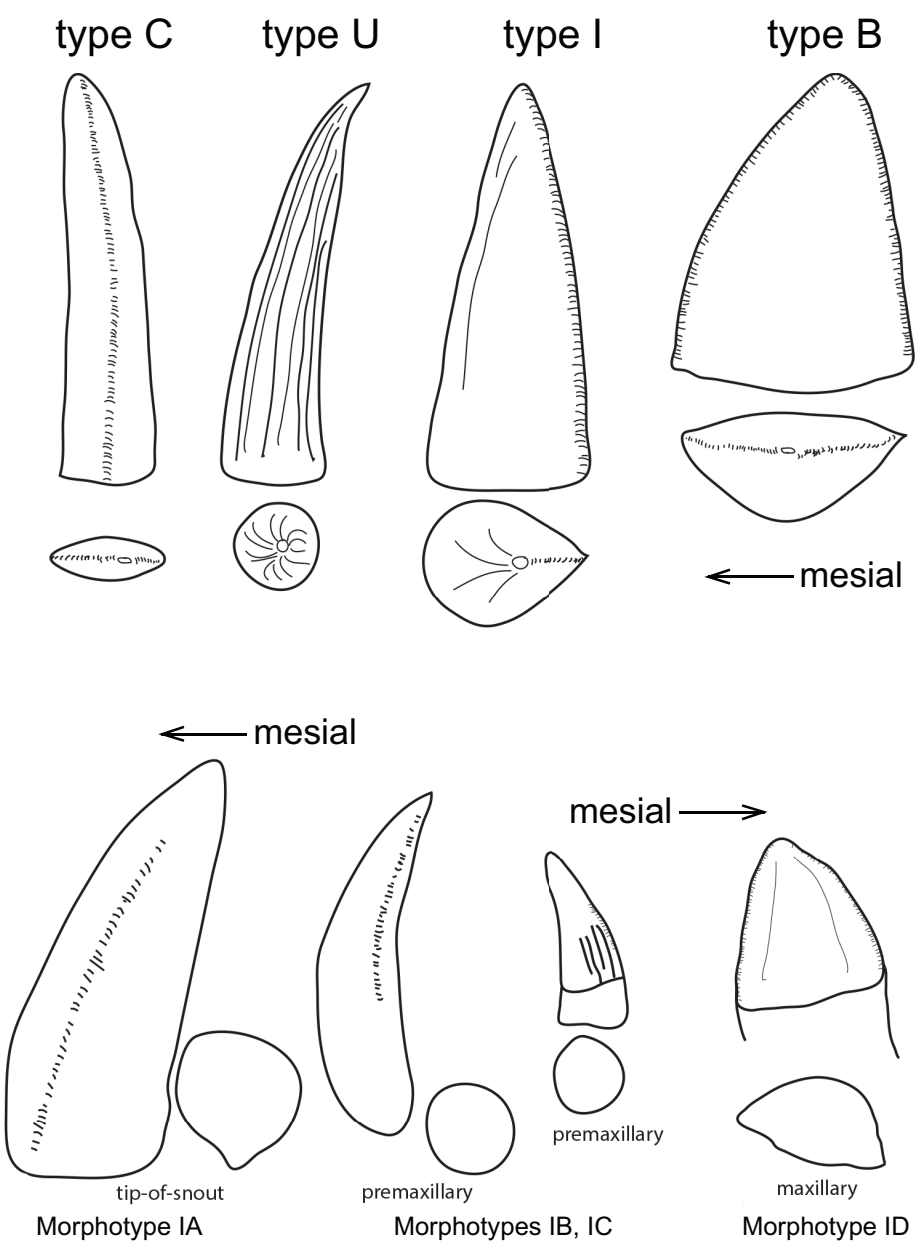

B

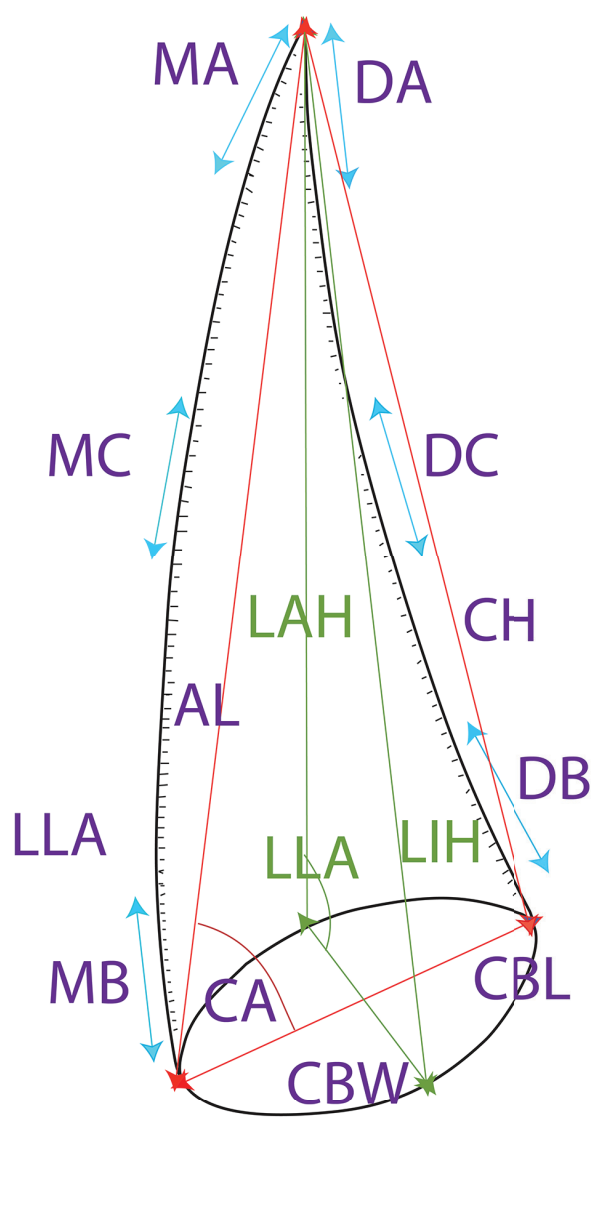

FIGURE 2. Classification and measurement of the teeth sampled here. 2A-Idealized drawings of heterodont phytosaur teeth following Hunt (1989; type C, U, I, B), Hungerbühler (2001; tip-of-snout, premaxillary, maxillary), and Datta et al. (2021; morphotypes IA, IB, IC, ID). 2B-Schematic of macro-morphological measurements taken on phytosaur teeth as preservation allowed. Measurements following the protocols of Smith (2005) with purple labels: $\mathrm{CH}-\mathrm{crown}$ height, $\mathrm{CBL}$ — crown base length, $\mathrm{AL}$ —apical length, $\mathrm{CA}$ —crown angle (angle GAB), MA—mesial apical, MC—mesial mid-crown, and MB —-mesial basal denticle densities, DA—distal apical, DC—distal mid-crown, and DB—distal basal denticle densities, with measurements new to this study in green: $\mathrm{LAH}$-labial height, $\mathrm{LIH}$-lingual height, and LLA— labio-lingual angle.

Because phytosaur fossils are relatively common, widespread, and are known to occur in stratigraphic succession, they thus have great potential as biostratigraphic indicators. Indeed, multiple authors have hypothesized intercontinental correlations based on phytosaur occurrences (Colbert and Gregory, 1957; Hunt and Lucas, 1991; Long and Murry, 1995). Unfortunately, problems with taxonomy and endemic taxa have complicated these hypotheses (e.g., Brusatte et al., 2012; Jones and Butler, 2018). Still, within-basin phytosaur biostratigraphy remains robust in the southwestern US (e.g., Lucas and Tanner, 2007; Parker and Martz, 2011; Martz and Parker, 2017), hindered principally by the need for relatively complete skulls to verify identification at the generic and species level.

For decades, functional and phylogenetic studies have utilized dental microstructure of both extinct and extant amniotes (e.g., Johnston, 1979). Lines of von Ebner in dentine and lines of incremental growth (LIGs) in enamel provide records of growth with a resolution that may be as fine as daily (Appenzeller et al., 2005) and be equivalent to daily lines of von Ebner present in dentine (Button et al., 2017). The enamel microstructure (EM), or schmelzmuster, records the physical structure of the enamel and, in turn, informs hypotheses of tooth performance and function. Though much of 
this work has focused on mammals (e.g., Bromage and Dean, 1985; Koenigswald and Sander, 1997; Mao et al., 2017), studies of EM in diapsids are also promising (Buffetaut et al., 1986; Sander, 1999). These diapsid EM studies have explored questions of diet, phylogenetics, and uses for identifying isolated teeth (Sander, 1999; Stokosa, 2005; Hwang, 2010, 2011; Button et al., 2017). Though dinosaurs have received the greatest focus in diapsid studies (Hwang, 2005, 2010, 2011; Wang et al., 2015; Brink et al., 2015, 2016; Button et al., 2017), EM studies of squamates (e.g., Wintrich et al., 2017; Owocki and Madzia, 2020) and archosauriformes show functional and phylogenetic importance (e.g., Sander, 1999; Hwang, 2005; 2011; Heckert and Miller-Camp, 2013; Chen et al., 2018).

The only previously published work on phytosaur EM was conducted by Sander (1999) as part of his systematic sampling of reptilian tooth enamel. His study incorporated four isolated phytosaur teeth, three from the Upper Triassic Dockum Group of Texas, USA (Figure 1C) and one from the Rhaet Bonebed of Hallau, Switzerland (Sander, 1999). None of these teeth were associated with skulls or each other, and all were assigned to indeterminate phytosaurs (Sander, 1999). Phytosaur EM was unusual among the sampled reptile groups as some variation in structure and thickness was present, ranging from relatively thin $(\sim 20$ $\mu \mathrm{m}$ thick) parallel crystallite enamel to considerably thicker (> $150 \mu \mathrm{m})$ columnar enamel (Sander, 1999). Two of the Dockum teeth were composed of thin $(<20 \mu \mathrm{m}$ thick) parallel enamel with prominent incremental lines and no basal unit. The third Dockum tooth had a maximum enamel thickness of $150 \mu \mathrm{m}$, columnar enamel and a basal unit. The Swiss tooth was incomplete, so the apparent maximum thickness of $\sim 60 \mu \mathrm{m}$ could be greater, with columnar enamel and rare incremental lines. If such variation were to be phylogenetically constrained, then the possibility of generic-, or species-level identification of isolated phytosaur teeth may be possible. Additionally, by sampling teeth of various positions in heterodont taxa, we will evaluate the hypothesis of differential function of mesial to distal teeth. This study builds off of the unpublished undergraduate honors thesis of author JM-C (Camp and Heckert, 2007; Camp, 2007).

\section{Institutional Abbreviations}

NCSM - North Carolina Museum of Natural Sciences, Raleigh, NC; NMMNH - New Mexico Museum of Natural History, Albuquerque, NM;
USNM-United States National Museum (Smithsonian), Washington, DC.

\section{MATERIALS AND METHODS}

We examined the EM of 23 teeth from several heterodont phytosaur taxa from western (NMMNH localities) and eastern (NCSM localities) North America (Table 1; Figure 3), thereby greatly increasing the sampling conducted ( $n=4$ teeth from two localities) of Sander (1999). The localities represent the four land vertebrate "faunachrons" (LVF) or holochrons of the Late Triassic of North America (Lucas and Hunt, 1993; Martz and Parker, 2017). We assign teeth to Phytosauria based on the general morphology of each tooth type including large, conical, and recurved with long and low ridges on the enamel (type $\mathrm{C}$ ); conical and unserrated, with fluting along the crown (type U); conical shape and mesial and distal carinae (type I); and mesial-distally elongate with somewhat mesial and distal carinae (type B) (Figure 2). The most robust sampling strategy would be to sample a series of teeth from individual skulls that are unambiguously assigned to known taxa, however, there are numerous logistical hurdles, including not only the destructive nature of EM sampling, but also the fact that, despite their possession of more than 150 tooth positions, relatively few phytosaur skulls and lower jaws preserve multiple in situ teeth from all parts of the dentition. Therefore, we felt it most reasonable to first survey representative isolated teeth from stratigraphically superposed localities yielding heterodont phytosaurs. To minimize taxonomic uncertainty, we have selected teeth from localities where only one phytosaur taxon is known, excepting the oldest, which has an additional homodont taxon.

We attempted to select teeth that represented types C, U, I, and B from each locality as described in the "Sampling Strategy" section. In situ teeth were not available for sampling, so we identified each tooth morphotype based on the criteria outlined by Hunt (1989), but note that identification of type $\mathrm{C}$ teeth is somewhat tentative, as it can be difficult to tell larger type I teeth from smaller individuals' type $C$ teeth (Figure 2A; Hungerbühler, 2000).

Macroscopic measurements were taken following the protocols of Smith (2005) prior to embedding to account for possible size-related enamel variation. Although Smith's (2005) analysis focused on theropod dinosaurs, the measurements that he used are broadly applicable to the conidont (types C, I, U) to ziphodont (type B) dentition of phytosaurs. To these data we added three new 
Hoffman, Miller-Camp, \& Heckert: Phytosaur tooth enamel

TABLE 1. All specimens used in our study, organized by holochron and then locality with tooth type assignments and presence (marked with "X") or absence of BUL and LIG.

\begin{tabular}{|c|c|c|c|c|c|}
\hline Holochron & Locality & Specimen Number & Tooth Type & BUL & LIG \\
\hline \multirow[t]{3}{*}{ Apachean } & NMMNH L-4211 & NMMNH P-36184 & 1 & & $x$ \\
\hline & & NMMNH P-36185 & I & $x$ & \\
\hline & & NMMNH P-36186 & B & $x$ & \\
\hline \multirow[t]{4}{*}{ Revueltian } & NMMNH L-3845 & NMMNH P-33103 & $u$ & & $x$ \\
\hline & & NMMNH P-33105 & 1 & $x$ & \\
\hline & & NMMNH P-33106 & B & & \\
\hline & & NMMNH P-33593 & I & & \\
\hline \multirow[t]{13}{*}{ Adamanian } & NCPaleo 0401 & NCSM 23303 & B & & $x$ \\
\hline & & NCSM 24322A & $U$ & $x$ & $x$ \\
\hline & & NCSM 24322B & U & $x$ & $x$ \\
\hline & & NCSM 25043 & C & & $x$ \\
\hline & & NCSM 25075 & I & & $x$ \\
\hline & NMMNH L-6818 & NMMNH P-36145 & I & $x$ & \\
\hline & & NMMNH P-36146 & $U$ & & \\
\hline & & NMMNH P-36147 & B & & \\
\hline & & NMMNH P-36148 & B & & $x$ \\
\hline & NMMNH L-3104 & NMMNH P-59647 & I & & \\
\hline & & NMMNH P-59648 & $U$ & $x$ & \\
\hline & & NMMNH P-59649 & I & & \\
\hline & & NMMNH P-59650 & $\mathrm{B}$ & $x$ & \\
\hline \multirow[t]{3}{*}{ Otischalkian } & NMMNH L-582 & NMMNH P-36190 & I & & $x$ \\
\hline & & NMMNH P-36191 & B & & \\
\hline & & NMMNH P-36192 & $\mathrm{B}$ & & \\
\hline
\end{tabular}

measurements-labial height (LAH), lingual height (LIH), and labio-lingual angle (LLA) - to capture the labio-lingual recurvature exhibited by some phytosaur teeth (Figure 2B).

The teeth were embedded in epoxy then sectioned transversely, longitudinally, and tangentially, as in previous reptilian enamel studies (Sander, 1999; Hwang, 2005, 2010, 2011). Transverse sections were made at or just below the midline of the crown (half of $\mathrm{CH}$ ), and longitudinal sections were made through the carinae to examine enamel variation along the denticles. All sections were etched in $5 \% \mathrm{HCl}$ for one minute, cleaned in an ultrasonic bath for 45 seconds, then sputter coated in gold for two minutes at $18 \mathrm{~mA}$ in a Polaron SEM Coating System. Representative images were taken of each tooth using a scanning electron microscope (Quanta 200 ESEM-SEM) housed at the College of Arts and Sciences microscopy facility at Appalachian State University, Boone, North Carolina.

Within our study we have followed the "best practices" outlined in Heckert and Miller-Camp
(2013). To do this we took all our sections at the same approximate point on each tooth and describe qualitative features as well as record multiple measurements across the plane of section. Particularly, we report minimum and maximum enamel thicknesses for each tooth, as enamel thickness can vary not only within taxa, but within individual teeth as well (e.g., Sander, 1999; Heckert and Miller-Camp, 2013). When possible, we took tooth measurements prior to embedding and sectioning, so that after enamel measurements were taken, we could contextualize based on the overall size of the tooth. As Heckert and MillerCamp (2013) noted, it is not enamel thickness, but the relative enamel thickness, that is likely constrained, and so overall comparisons of thickness from one phytosaur genus to another, is not meaningful without accounting for tooth size.

EM was analyzed qualitatively and quantitatively. Qualitative assessment included identification of enamel types (e.g., parallel or columnar), features of the basal unit layer (BUL), and LIGs. 


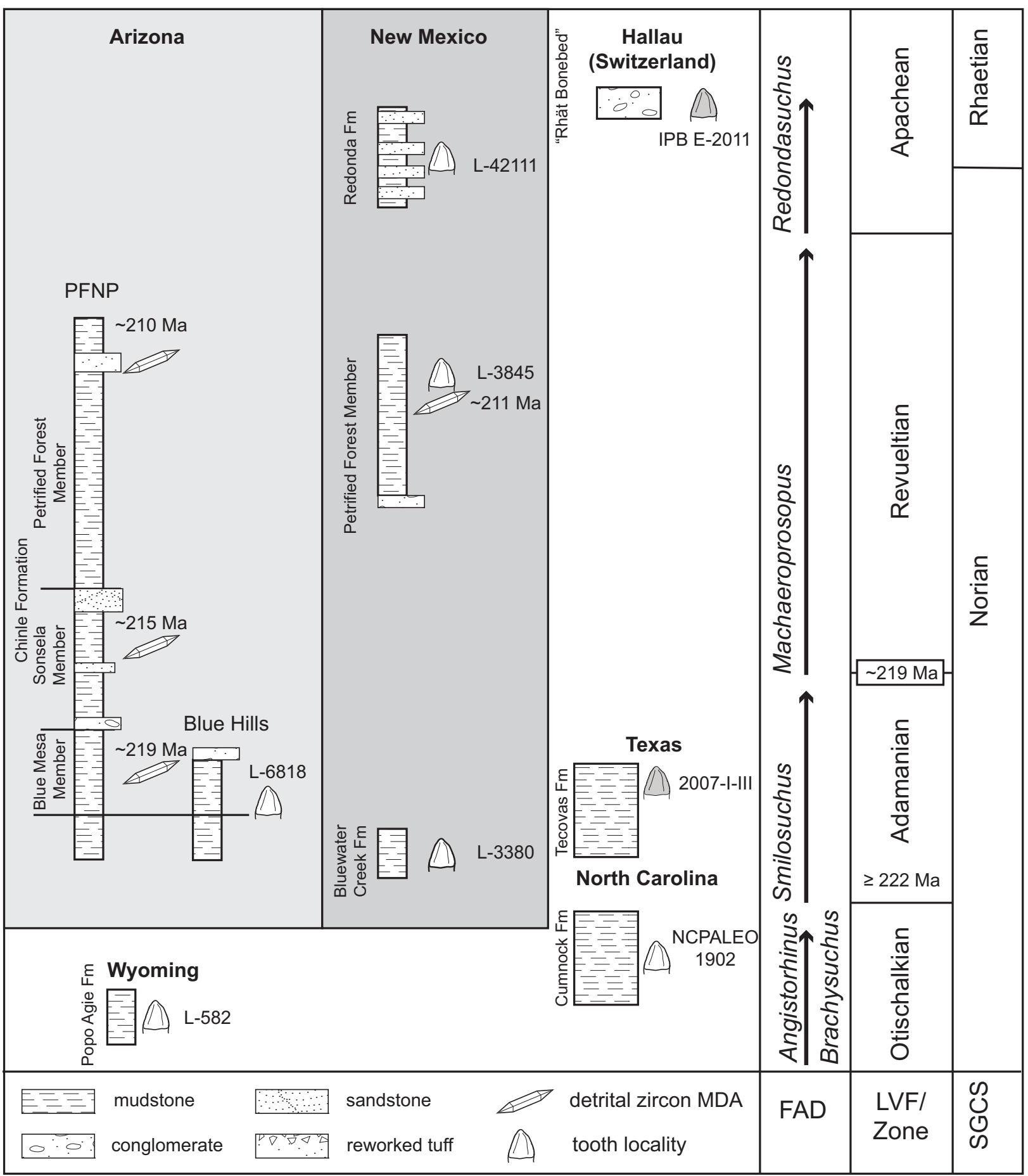

FIGURE 3. Generalized stratigraphic distribution of the phytosaur teeth sampled here (L-3380, L-3845, L-4211, L6818, NCPALEO1902) and by Sander (1999; IPB E-2011, 2007I-III) compared to stratigraphic distribution of heterodont phytosaurs, North American biostratigraphy, and the standard global chronostratigraphic scale (SGCS). See text for details of the stratigraphy of each locality. Numerical age estimates draw on a variety of sources, including Heckert et al., 2009; Irmis et al., 2011; Ramezani et al., 2011; Whiteside et al., 2011. FAD = First appearance datum; L- = locality numbers for New Mexico Museum of Natural History and Science; LVF = Land-vertebrate faunachron (= "holochron"); NCPaleo = Locality for North Carolina Museum of Natural Sciences. 
We use the reptilian enamel microstructure (EM) terminology defined by Sander (1999), excepting the use of lines of incremental growth (LIGs; Hwang 2005) for interruptions of enamel growth (= "incremental lines" of Sanders (1999) and "striae of Retzius" in mammalian literature (Bromage and Dean, 1985)). The quantitative measurements (enamel thickness, column width, and BUL thickness) were taken using Image J v1.48 (Abramoff et al., 2004). Data were tested for normality using Shapiro-Wilk and visually using density and $Q-Q$ plots prior to analysis of variance (ANOVA), followed by a Least Significant Difference (LSD) post hoc test of enamel thickness between tooth types was run in IBM SPSS v22. We tested absolute difference as well as relative difference controlling for size by dividing enamel thickness by crown height before performing the ANOVA. As we had only one definitively type $C$ tooth in our study, the statistical analyses were limited to types $\mathrm{U}, \mathrm{I}$, and $\mathrm{B}$.

Enamel microstructure studies are in nearunanimous agreement that EM should be examined in all three possible views (transverse, longitudinal, and tangential) whenever possible. To facilitate comparison, we have added an icon on each EM image (Figures 4-8) that shows the approximate location of the section on the tooth and type of section (transverse, longitudinal, and tangential).

\section{SAMPLING STRATEGY}

\section{Otischalkian-Angistorhinus}

The oldest LVF is represented by locality NMMNH L-582 in the Popo Agie Formation of Wyoming (Lucas et al., 2002). The age assignment is based primarily on the occurrence of early diverging phytosaurs-particularly Parasuchus (= Paleorhinus) and Angistorhinus (Brachysuchus ?) as well as the rhynchosaur Hyperodapedon (Mehl, 1913, 1928; Lucas, 1994, 1998; Lucas et al., 2002). There is one very large specimen of a Parasuchus-grade phytosaur (Lucas et al., 2007), but the dentition is not preserved in that specimen, so, although we cannot be certain these teeth all represent Angistorhinus and not Parasuchus, Angistorhinus is the only taxon known from the Popo Agie with a demonstrably heterodont dentition. We sectioned and measured three teeth: one type I tooth (NMMNH P-36190) and two type B teeth (NMMNH P-36191; NMMNH P-36192).

\section{Adamanian-Smilosuchus}

The Adamanian is represented by two localities: NMMNH L-3380 in New Mexico and NMMNH L-6818 in Arizona, of which L-3380 is the stratigraphically lowest. NMMNH L-3380 is low in the Bluewater Creek Formation in the Lucero Uplift of central New Mexico and is the most stratigraphically and taxonomically ambiguous locality sampled. No complete phytosaur skulls are known from this outcrop belt, but an incomplete postcranial skeleton of a phytosaur tentatively referred to Smilosuchus was recovered from nearly the same stratigraphic level nearby and described by Heckert (1999). Based on this and other lines of evidence, these localities are assigned to the Admanian LVF (e.g., Lucas and Heckert, 1994; Heckert, 1999), and thus Smilosuchus is the most likely candidate for a heterodont phytosaur from this locality.

NMMNH L-6818 is in the basal beds of the Blue Mesa Member of the Petrified Forest Formation (=Chinle Formation) in the Blue Hills of eastern Arizona. It contains numerous Adamanian index taxa and is the type assemblage of the St. Johnsian sub-LVF (Hunt et al., 2005). Phytosaurs from the Blue Hills have been referred to a variety of taxa, currently recognized as Smilosuchus gregorii (Camp) and "Machaeroprosopus" zunii Camp (1930) by Stocker and Butler (2013). The latter was referred to Leptosuchus adamanensis by Long and Murry (1995), and "Rutiodon" spp. (Heckert and Lucas, 2003; Heckert et al., 2005) and Leptosuchus gregorii (Irmis, 2005), and this is in fact the type locality for Camp's "Machaeroprosopus" zunii. The postcrania of " $M$." zunii strongly resemble those of Smilosuchus, and there is a very large skull of Smilosuchus (USNM 18313) known from the Blue Hills, so we feel confident in assigning these teeth to Smilosuchus, which is more strongly heterodont than any species of Leptosuchus (= "Rutiodon" of some workers).

The base of the Blue Mesa Member in the Blue Hills has a maximum depositional age of $220.9 \pm 0.6 \mathrm{Ma}$ based on $\mathrm{U}-\mathrm{Pb}$ dating of detrital zircons (Heckert et al., 2009), which agrees well with other ages from the base of the member elsewhere, especially in Sixmile Canyon to the east in New Mexico (Heckert et al., 2009; Irmis et al., 2011; Ramezani et al., 2011). Recently Marsh et al. (2019) have argued that the Blue Mesa Member is absent in western New Mexico and parts of Arizona, and instead that the horizon yielding detrital zircons with a maximum depositional age pertains to the Sonsela Member, which changes the names 
A

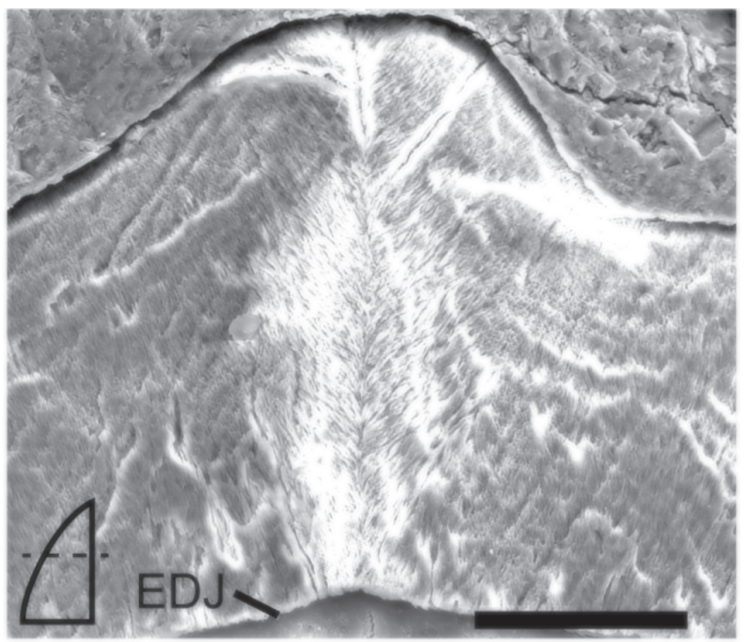

C

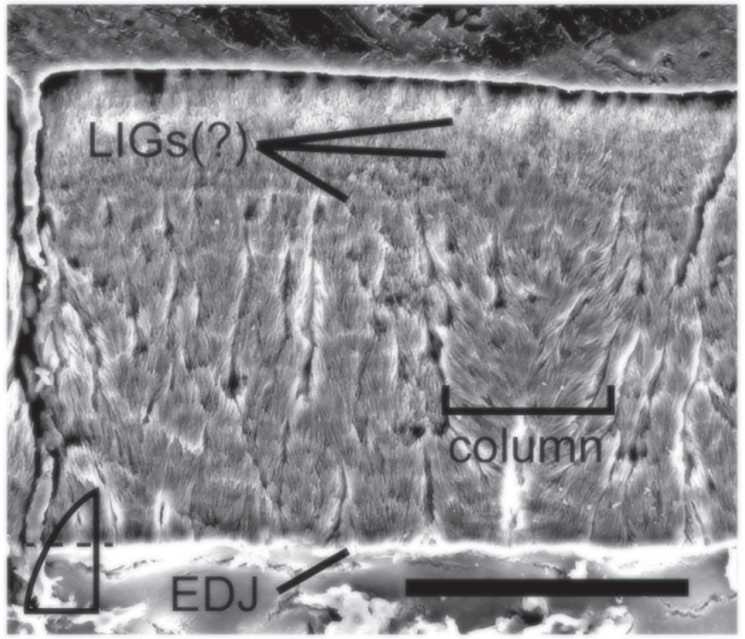

E

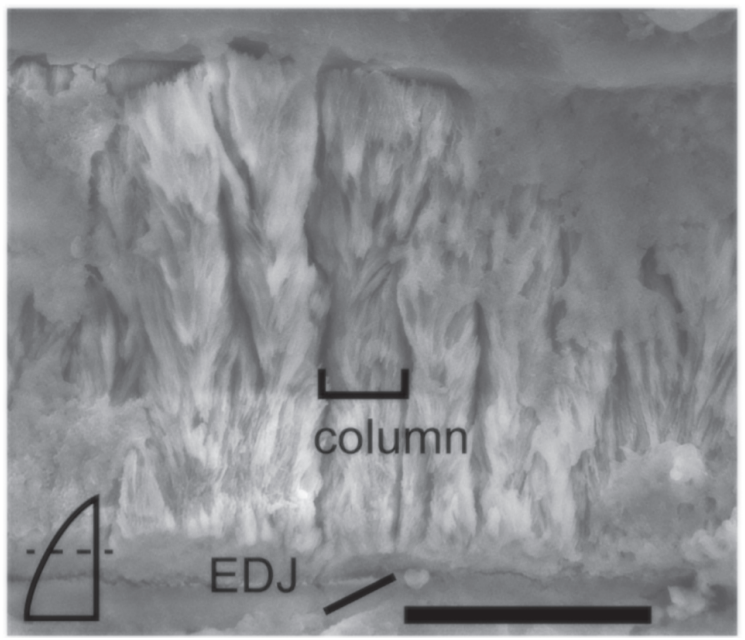

B

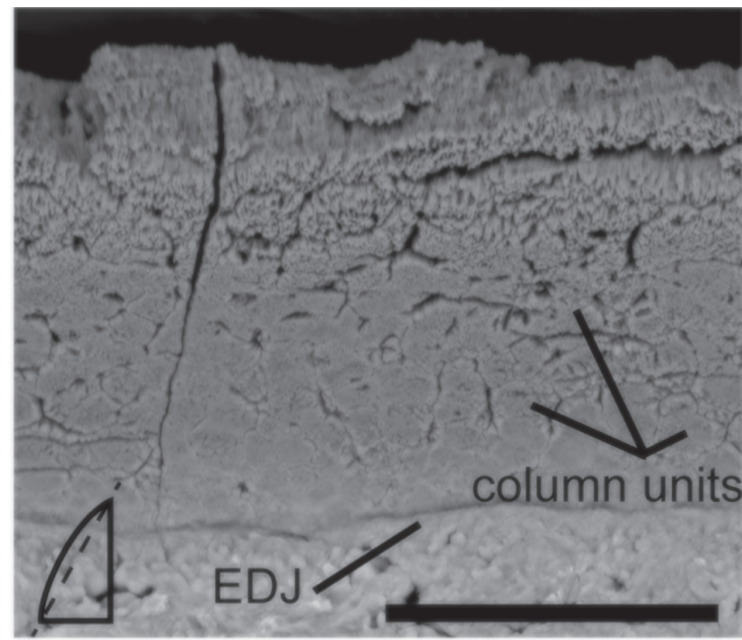

$\mathrm{D}$

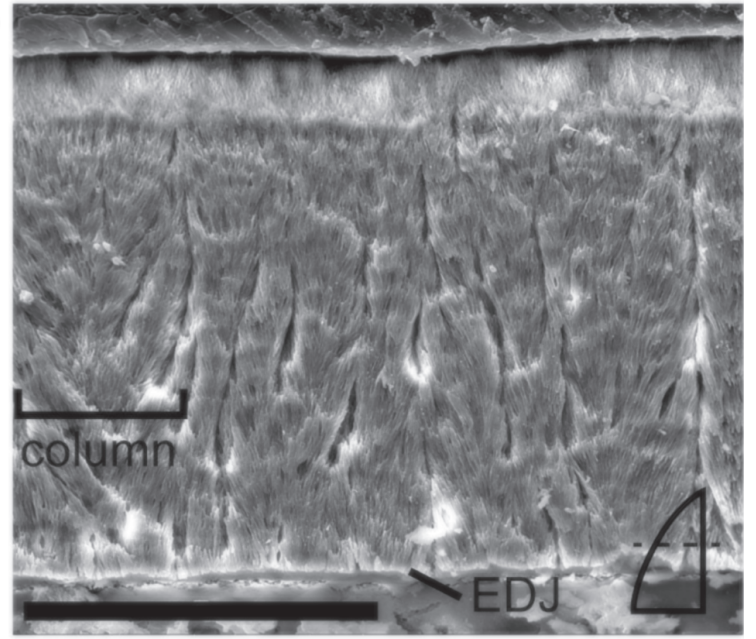

F

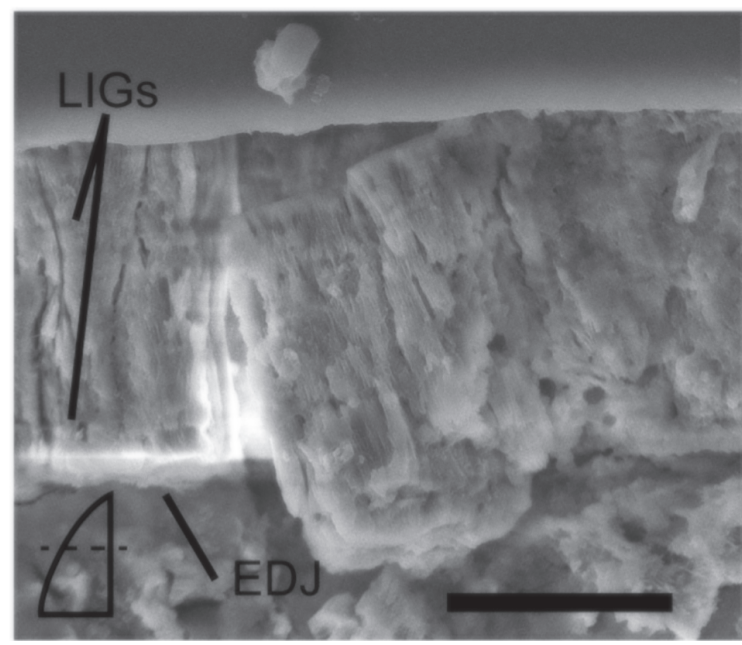

FIGURE 4. SEM captures of Angistorhinus teeth from the Popo Agie Formation of Wyoming. 4A-NMMNH P-36190 type I tooth, transverse section across a denticle; 4B-NMMNH P-36190 type I tooth tangential view of enamel, polygonal columnar enamel packages evident on lower half of image; 4C-NMMNH P-36190 type I tooth enamel from labial margin of tooth; 4D-NMMNH P-36190 type I tooth enamel from lingual margin of tooth; 4E-NMMNH P-36192 type B tooth enamel preserves thin columnar packages; 4F-NMMNH P-36191 type B tooth with a few faint LIGs near OES. All scale bars equal $50 \mu \mathrm{m}$. 
A

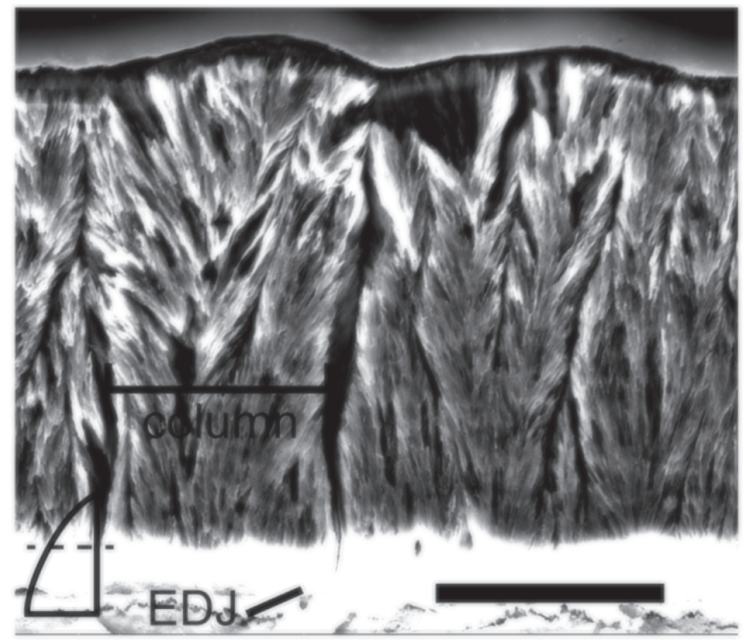

C

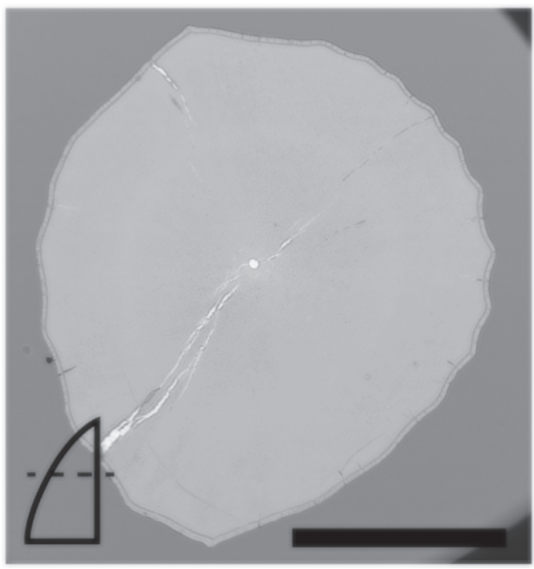

$\mathrm{E}$

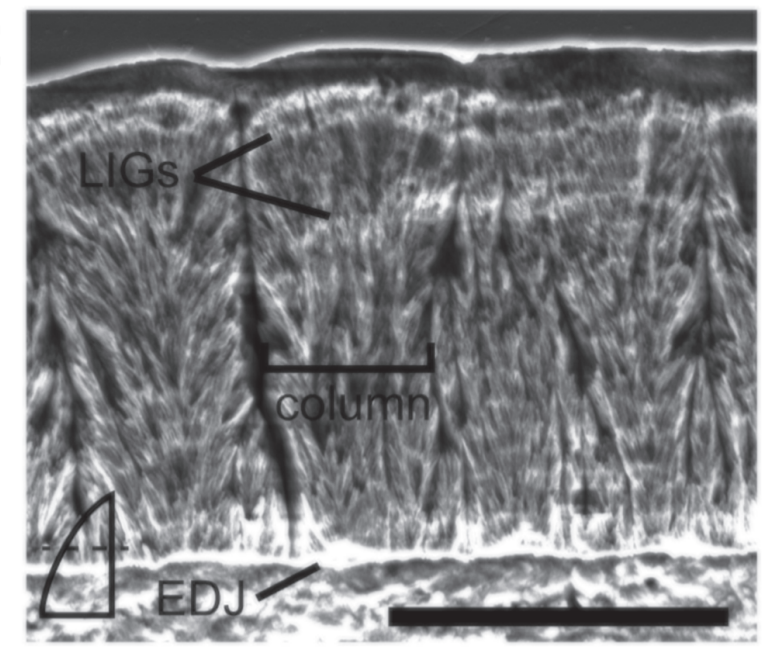

B

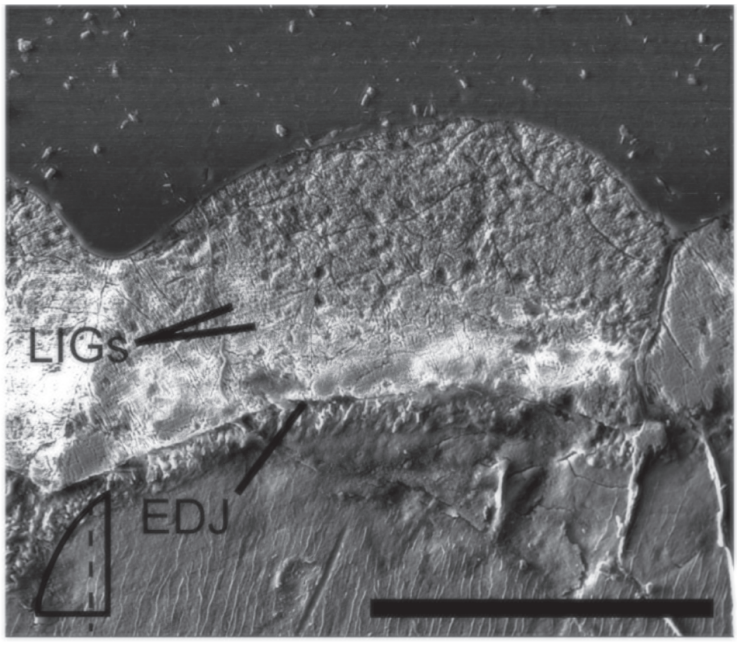

$\mathrm{D}$

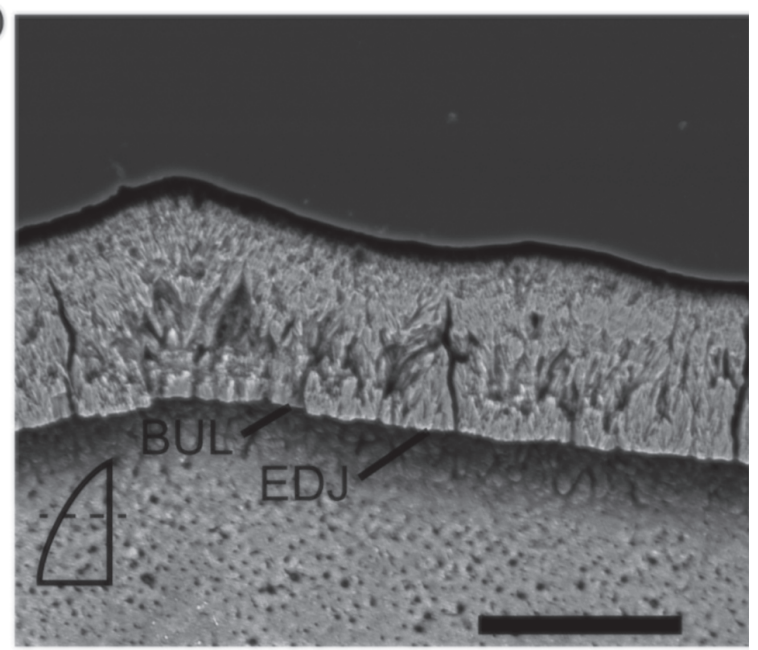

F

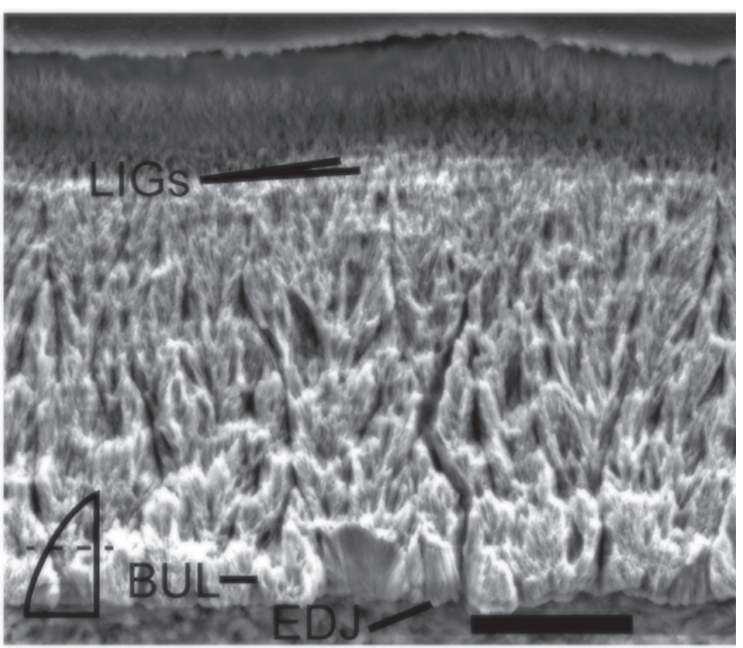

FIGURE 5. SEM captures of Smilosuchus teeth from the lower Chinle of New Mexico (4.1-2) and Arizona (4.3-6). 5A-NMMNH P-36146 type $U$ tooth with well-developed columns; 5B-NMMNH P-36148 type B tooth in longitudinal view along the carina with faint LIGs in the inner half of the enamel; $5 \mathrm{C}-\mathrm{NMMNH} 59648$ type $\mathrm{U}$ tooth overview of transverse section showing the contributions of enamel and dentine to the fluting; 5D-NMMNH P-59648 type U tooth fluting along lingual surface; 5E-NMMNH P-59650 type B tooth along labial margin of enamel with well-developed columns; 5F-NMMNH P-59650 type B tooth along lingual margin of enamel. Scale bars for 5.1, 5.4-6 equal $50 \mu \mathrm{m}$, 5.2 scale bar equals $100 \mu \mathrm{m}$ and 5.3 scale bar equals $2 \mathrm{~mm}$. 
applied to lithostratigraphic correlations, and suggests that localities in the Blue Hills are stratigraphically higher than previously appreciated, but still recognizes this assemblage as being a relatively young occurrence of Adamanian taxa.

We sectioned and imaged a total of nine teeth that we assign to Smilosuchus, four from L-6818 in Arizona and five from L-3380 in New Mexico.The Arizona Smilosuchus teeth include one type $U$ (NMMNH P-59648), two type I (NMMNH P-59647, NMMNH P-59649) and one type B (NMMNH 59650). The New Mexico Smilosuchus teeth include one type U (NMMNH P-36146), one type I (NMMNH P-36145), and two type B teeth (NMMNH P-36147, NMMNH P-36148).

\section{Adamanian-"Rutiodon"}

The taxonomic status of phytosaurs from eastern North America is more problematic than in the west, largely due to a paucity of preserved, identifiable material and the fact that the known fossils were recovered from a variety of Newark Supergroup basins, leading to stratigraphic correlation and age constraint issues (Hunt and Lucas, 1989; Stocker and Butler, 2013). The teeth we sampled were collected from NCPaleo 0401, which consists of artificial exposures of the Cumnock Formation in a brick quarry in the Wadesboro sub-basin of North Carolina (Litwin and Ash, 1993). The age of the Cumnock Formation has been debated, but recent estimates place it at approximately $225 \mathrm{Ma}$ (Whiteside et al., 2011; see Heckert et al., 2012 for discussion). The vertebrate assemblage at this locality is still under study, but the Cumnock Formation in the more central Sanford sub-basin has yielded the type and some referred material of Rutiodon carolinensis Emmons 1856, including $\mathrm{AMNH} 1$, a complete skeleton (McGregor, 1906; Colbert et al., 1947; Hunt and Lucas, 1989). This assignment is tentative, as Rutiodon has been used as a wastebasket taxon for Newark Supergroup phytosaurs (Stocker and Butler, 2013; Jones and Butler, 2018). The Wadesboro teeth can only confidently be referred to Phytosauridae indet., but could well represent the true heterodont "Rutiodon-like" phytosaur from the Cumnock Formation, though resolving this is beyond the scope of this project, see Jones and Butler (2018) for the most recent discussion of Rutiodon synonymy.

We sectioned and imaged five teeth assigned to "Rutiodon": one possible type C (NCSM 25043), two type U (NCSM 24322A, NCSM 24322B), one type I (NCSM 25075), and one type B tooth (NCSM 23303).

\section{Revueltian-Machaeroprosopus}

The Revueltian is represented by NMMNH locality 3845, the "Snyder Quarry", in the Painted Desert Member (=Petrified Forest Member) of the Petrified Forest Formation (=Chinle Formation) (Zeigler et al., 2005; Martz and Parker, 2017). The Snyder Quarry is an extremely prolific bonebed that yields multiple skulls and abundant postcrania of Machaeroprosopus (=Pseudopalatus) buceros (Cope, 1881; e.g., Zeigler et al., 2002; 2003a,b,c). As Machaeroprosopus is the only phytosaur recorded from this site, we are confident in this assignment. This phytosaur and the aetosaurs Typothorax coccinarum and Rioarribasuchus chamaensis are all considered index fossils of the Revueltian land vertebrate faunachron and have all been recovered from the Snyder Quarry (Zeigler et al., 2003a,b,c; Lucas et al., 2007). We sectioned and imaged four teeth assigned to the genus Machaeroprosopus: one type $\mathrm{U}$ (NMMNH P33103), two type I (NMMNH P-33105, NMMNH P33593), and one type B tooth (NMMNH P-33106).

\section{Apachean-Redondasaurus}

The youngest LVF is represented by NMMNH L-4211 in the Duke Ranch Member of the Redonda Formation (Spielmann and Lucas, 2012). This site yielded a giant, incomplete skull and more fragmentary fossils assigned to Redondasaurus by Heckert et al. (2001) and R. gregorii by Spielmann and Lucas (2012). These teeth come from the same jacket as the skull, and so likely represent Redondasaurus, as no other phytosaur taxa are known from this formation. While some workers consider Redondasaurus to represent species of Machaeroprosopus (e.g., Hungerbühler et al., 2013), we retain the genus name here to represent the clade of Apachean phytosaurs recovered by recent analyses (e.g., Jones and Butler, 2018), even though that clade is nested within "Machaeroprosopus." We sectioned and imaged three teeth assigned to the genus Redondasaurus: two type I teeth (NMMNH P-36184; NMMNH P-36185) and one type $B$ tooth (NMMNH P-36186).

\section{RESULTS}

In the following sections we present our results taxonomically and in stratigraphic order from oldest to youngest. All taxa possess columnar enamel that varies in thickness from as little as 18 $\mu \mathrm{m}$ in some teeth to as much as $156 \mu \mathrm{m}$ in others. Basal unit layers (BUL) were not consistently pres- 


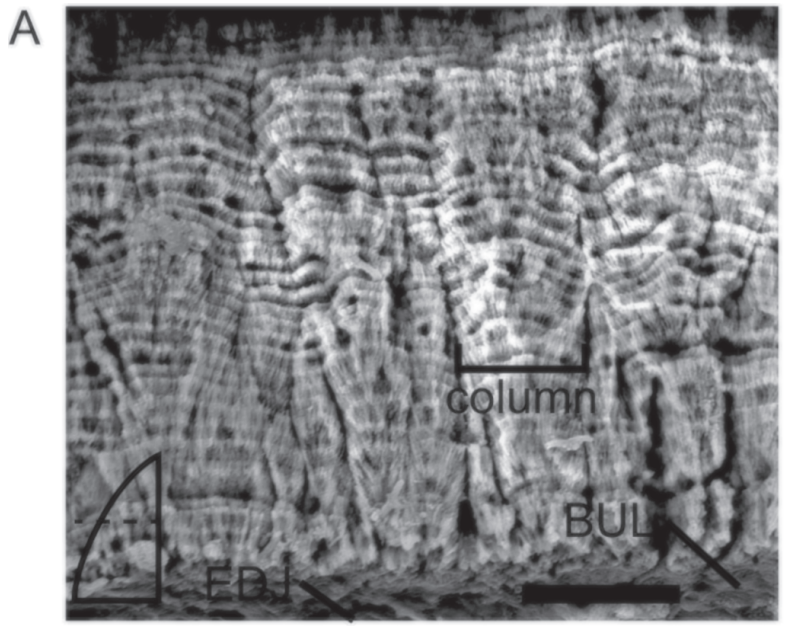

C

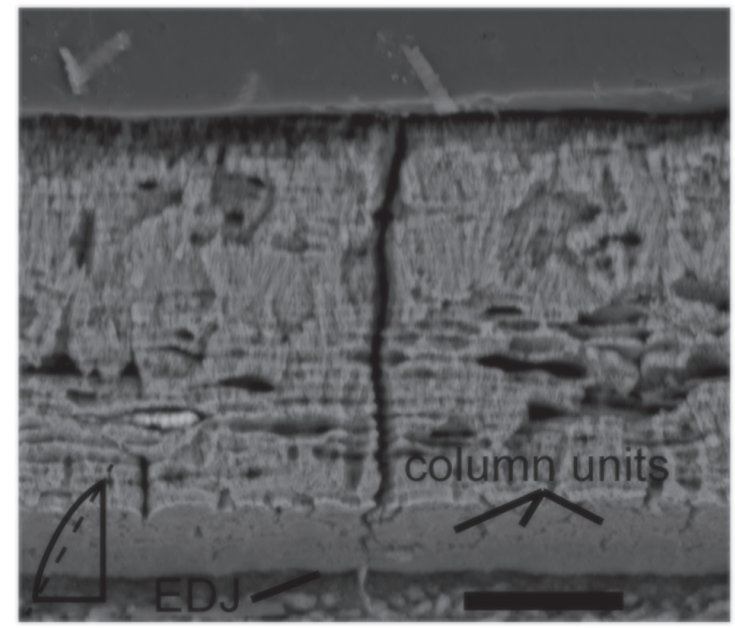

E

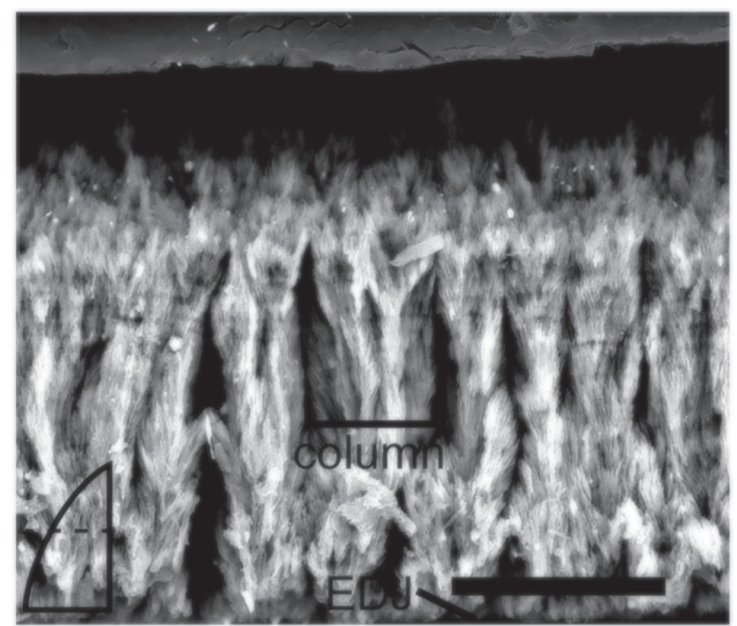

B

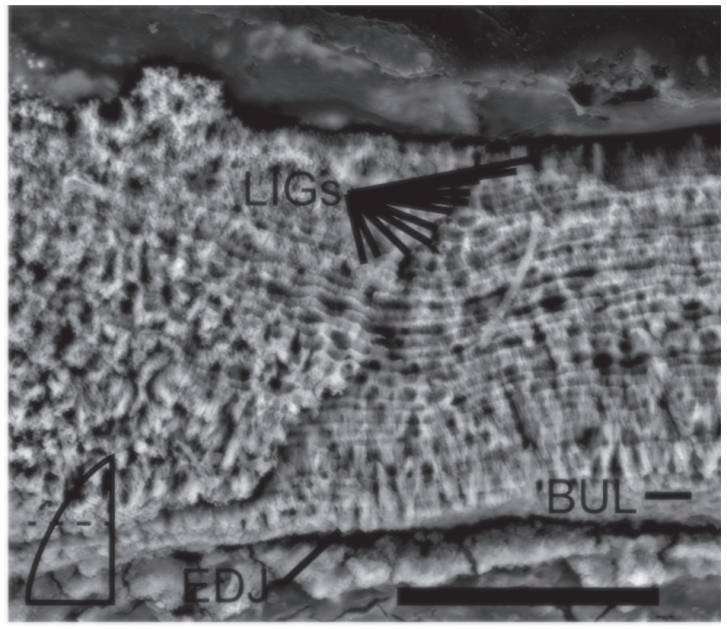

$\mathrm{D}$

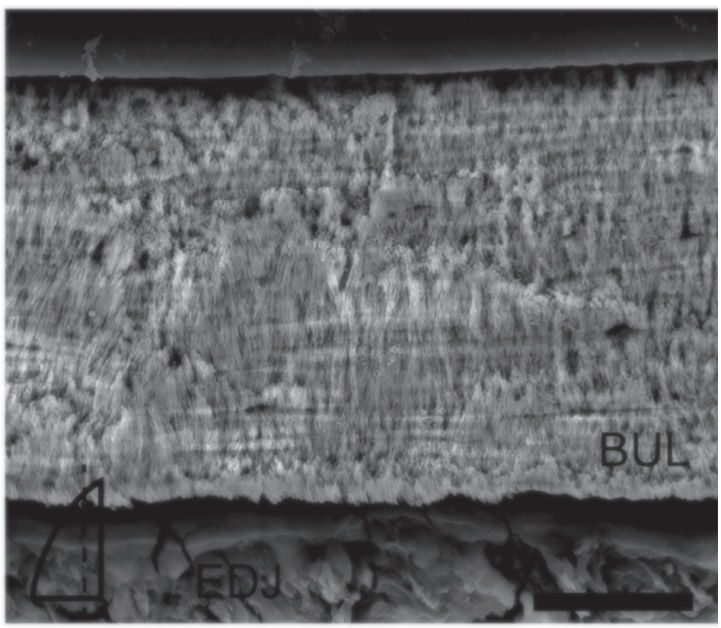

F

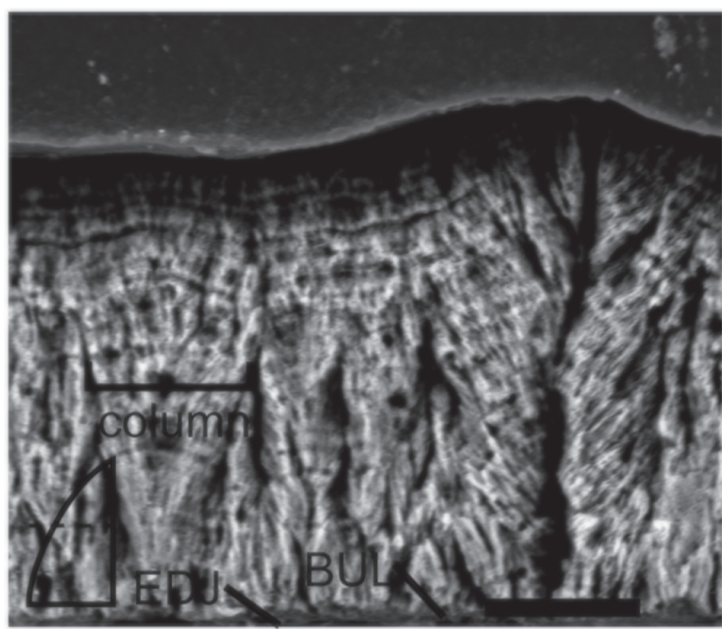

FIGURE 6. SEM captures of "Rutiodon" teeth. 6A-NCSM 23303 type B tooth in transverse section with well-developed columns along lingual margin and abundant LIGs; 6B-NCSM 23303 type B tooth in transverse section with well-developed columns along labial margin and abundant LIGs; 6C-NCSM 24322A type U tooth in tangential section showing polygonal columnar packages $\sim 10 \mu \mathrm{m}$ above EDJ with abundant LIGs; 6D-NCSM 24322B type $U$ tooth in longitudinal section showing minimum thickness of enamel along posterior margin just above tooth base with abundant LIGs; 6E-NCSM 25043 type C? tooth in transverse section with thin $(\sim 10 \mu \mathrm{m}$ wide) well-developed columnar enamel with abundant LIGs in outer half of enamel; 6F-NCSM 25075 type I tooth in transverse section of well-developed columnar enamel with abundant LIGs. All scale bars equal $50 \mu \mathrm{m}$. 

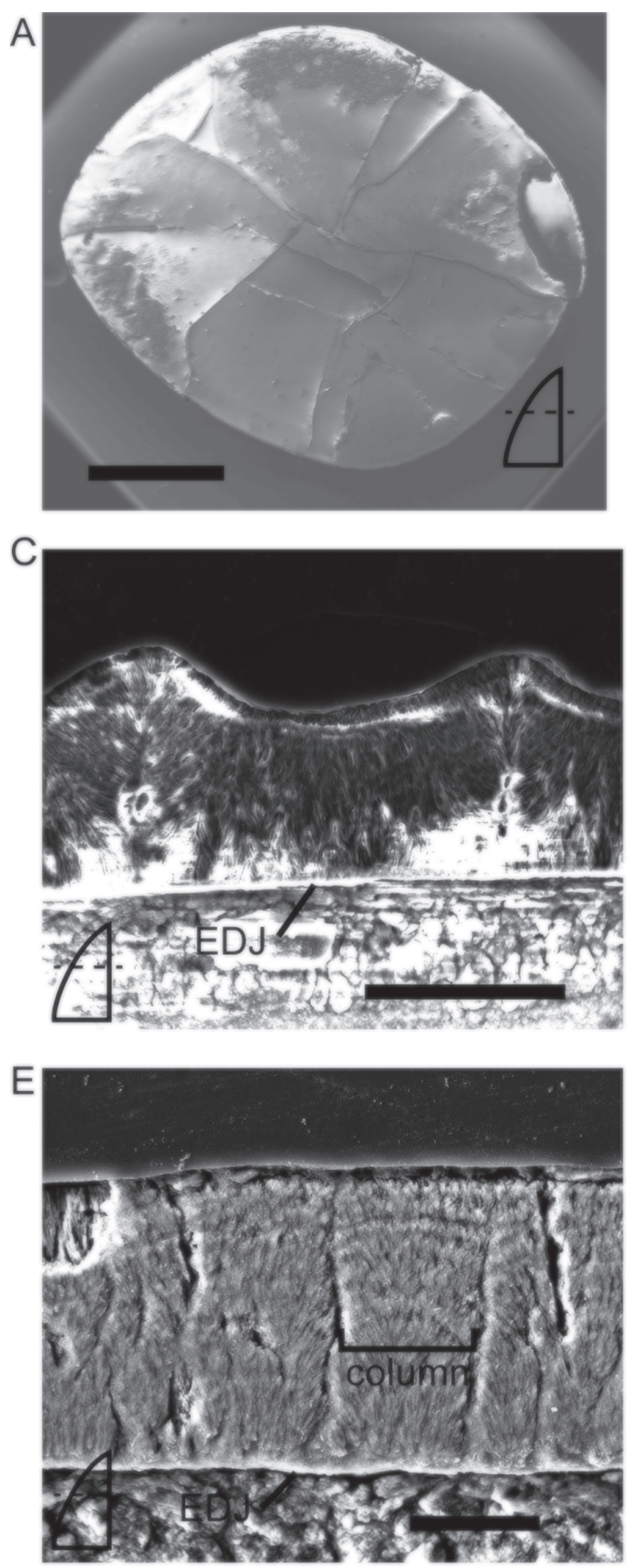

B

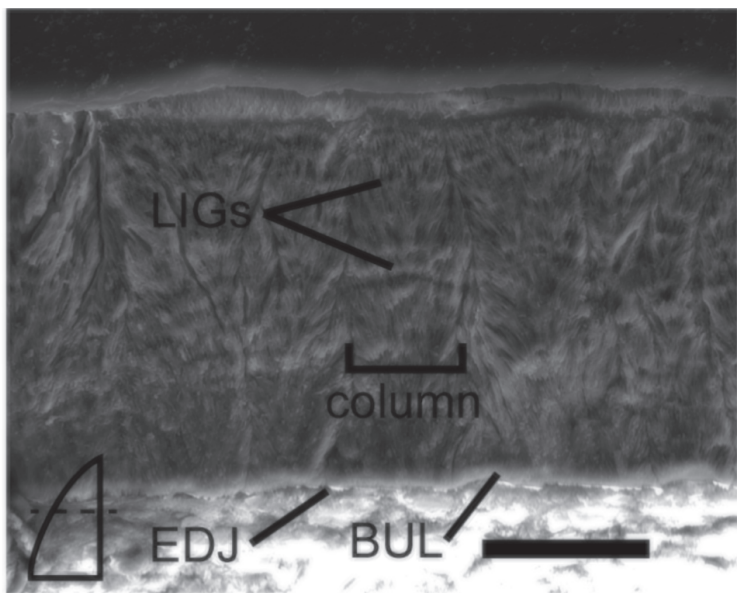

$\mathrm{D}$

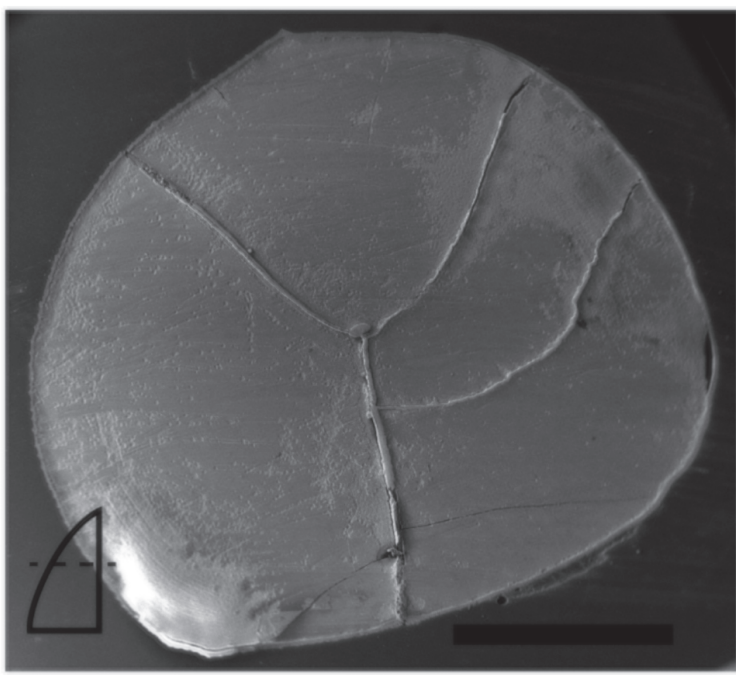

$\mathrm{F}$

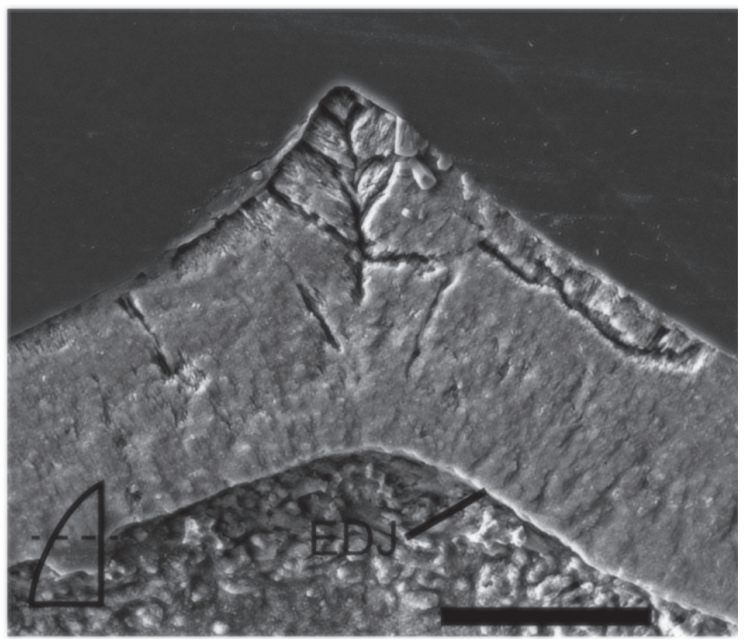

FIGURE 7. SEM captures of Machaeroprosopus teeth from the Petrified Forest Formation of New Mexico. 7ANMMNH P-33103 type $U$ tooth, overview of transverse cross-section; 7B-NMMNH P-33103 type U tooth with welldeveloped columns; 7C-NMMNH P-33103 type $U$ tooth fluting with contribution solely from the enamel; 7DNMMNH P-33105 type I tooth, overview of transverse cross-section; 7E-NMMNH P-33105 type I tooth denticle and maximum enamel thickness; 7F-NMMNH P-33105 type I tooth with well-developed columns. Both overview scale bars equal $2 \mathrm{~mm}$. Enamel image scale bars equal $50 \mu \mathrm{m}$. 
A

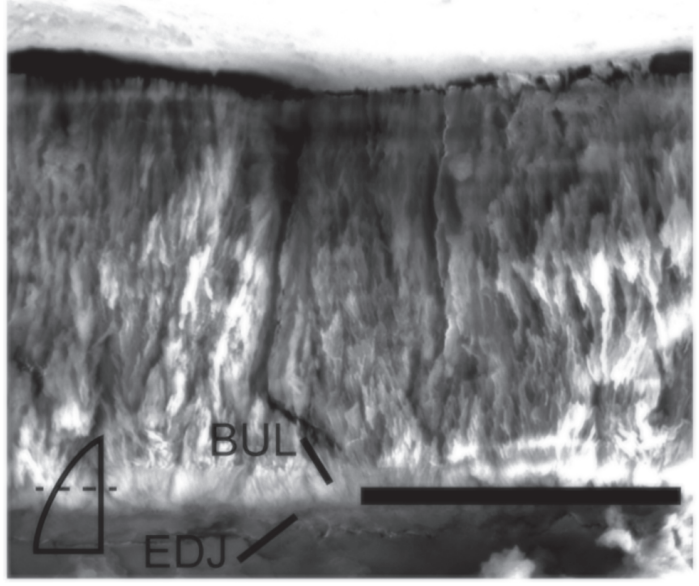

C

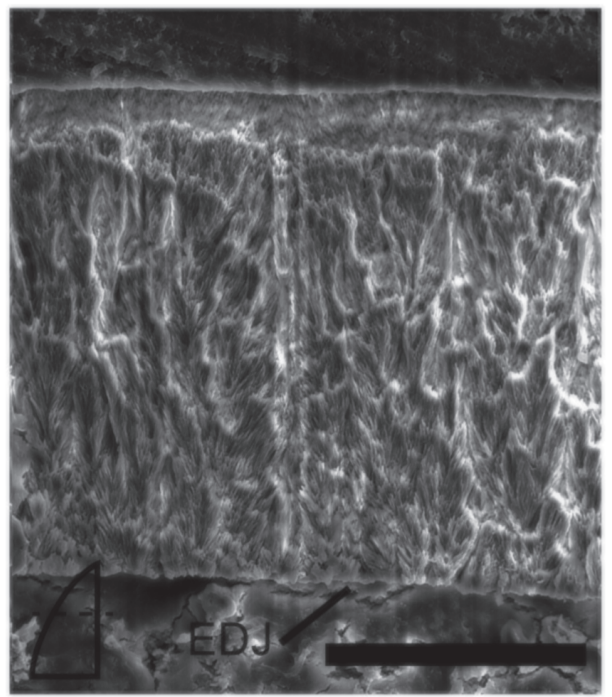

E

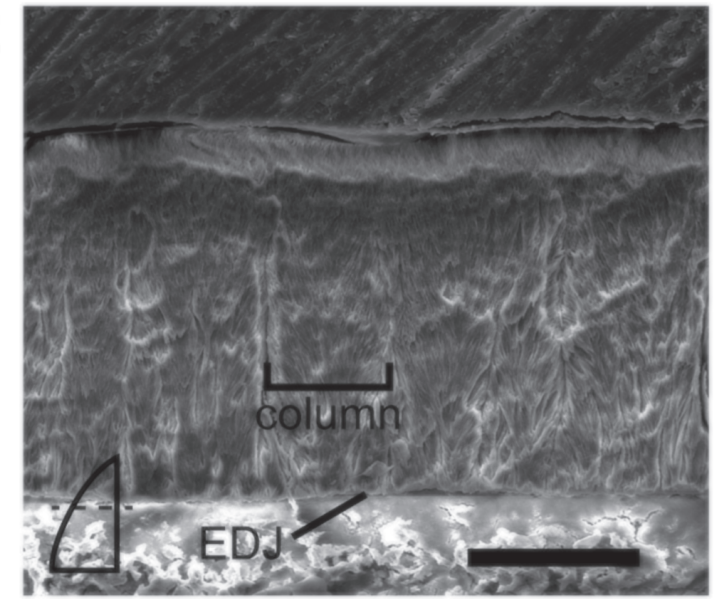

B

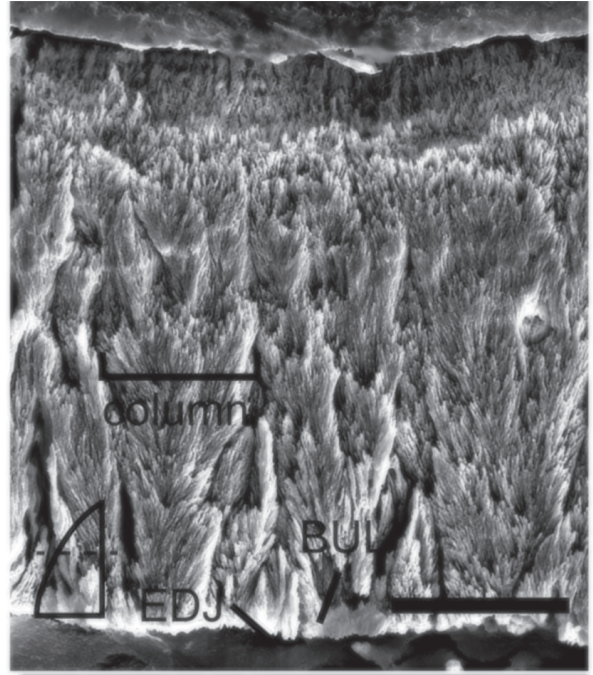

D
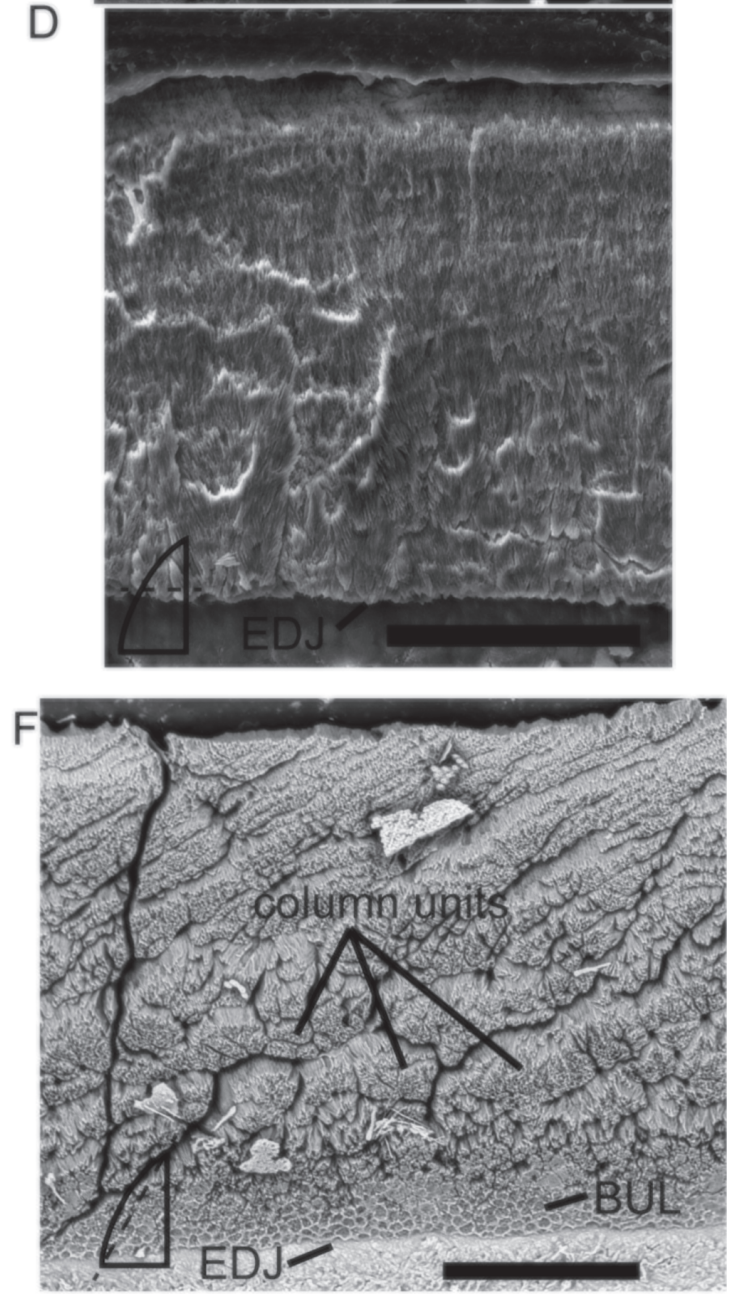

FIGURE 8. SEM captures of Redondasaurus teeth from the Redonda Formation of New Mexico. 8A-NMMNH P36184 type I tooth in transverse section with poorly-developed LIGs near OES as well as a few more near the center; 8B-NMMNH P-36185 type I tooth in transverse section with well-developed columns along lingual margin; 8CNMMNH P-36186 type B tooth in transverse section along labial margin; 8D-NMMNH P-36186 type B tooth in transverse section along lingual margin; 8E-NMMNH P-36186 type $B$ tooth in transverse section with well-developed columns; 8F-NMMNH P-36186 type B tooth in tangential section with $\sim 50 \mu \mathrm{m}$ at bottom of enamel, just above enameldentine junction (EDJ) showing polygonal columnar packages. All scale bars equal $50 \mu \mathrm{m}$. 
ent even within teeth and, when present, were almost always $<5 \mu \mathrm{m}$ thick.

\section{Otischalkian-Angistorhinus}

Enamel thickness of the type I tooth ranges from $73-131 \mu \mathrm{m}$ from the lingual edge to the center of the denticles (average of $84 \mu \mathrm{m}$ excluding the denticles themselves; Figure 4A-D). Type B tooth NMMNH P-36191 ranges from 27-37 $\mu \mathrm{m}$ (Figure $4 \mathrm{E}$ ). Measurements could only be taken at one location of the transverse section of type $B$ tooth NMMNH P-36192, where it ranged from 40-43 $\mu \mathrm{m}$.

Typically, Angistorhinus teeth lack a welldeveloped BUL, and columnar enamel emanates from the enamel-dentine junction (EDJ). The individual columnar units are readily discerned and vary in column width from 5-20 $\mu \mathrm{m}$ in the type B teeth and from 10-29 $\mu \mathrm{m}$ in the type I tooth (Figure 4C-D). These columnar packages of crystallites can also be clearly seen in tangential sections of columnar unit centers (Figure 4B). LIGs in Angistorhinus are uncommon, but three potential LIGs are visible on some images of NMMNH P-36190 (Figure $4 \mathrm{C}$ ). When LIGs are present, they typically occur near the outer enamel surface (OES) within the outer $\sim 25 \%$ of the enamel (Figure $4 \mathrm{E}$ ) yet can be scattered throughout (Figure 4F).

\section{Adamanian-Smilosuchus}

Enamel thickness of type $U$ teeth ranges from 36-72 $\mu \mathrm{m}$ at the crests of the subparallel ridges (fluting) (Figure 5A). Type I teeth range from 41-90 $\mu \mathrm{m}$ in enamel thickness. Type $B$ teeth range from $43 \mu \mathrm{m}$ thick to $156 \mu \mathrm{m}$ at the denticles (82 $\mu \mathrm{m}$ excluding the denticles; Figure 5B).

Some of the sampled Smilosuchus teeth preserve a BUL (Figure 5D,5F). Where, present, the BUL is generally thin $(\sim 5 \mu \mathrm{m})$, with well-developed columnar enamel originating from it. Contributions to the fluting seen on NMMNH P-59648 are made by both the enamel and, to a lesser extent, the underlying dentine such that the EDJ remains straight (Figure 5C). The enamel crystallites form columnar packages $12-27 \mu \mathrm{m}$ thick and are most clearly seen in the transverse sections (Figure 5DE). A handful of poorly developed LIGs are present and visible in both transverse (NMMNH P-36147; NMMNH P-59647) and longitudinal (NMMNH P36146) sections (Figure 5B). Unlike Angistorhinus, the LIGs of Smilosuchus are consistently present throughout the enamel layer (Figure 5B, 5E).

\section{Adamanian-“Rutiodon"}

The enamel thickness of the transverse section of type C tooth NCSM 25043 is fairly constant (42 $\mu \mathrm{m}$ to $44 \mu \mathrm{m}$ ). The two type $U$ teeth (NCSM $24322 \mathrm{~A}$ and $24322 \mathrm{~B}$ ) vary from $52-71 \mu \mathrm{m}$ from the base to the apex. The enamel of the type I tooth (NCSM 25075) spans from 51-66 $\mu \mathrm{m}$ at the carina. The type B tooth (NCSM 23303) possesses the greatest thickness and range of enamel from 42$100 \mu \mathrm{m}$, with the greatest thickness at the denticles (Figure 6A-B).

"Rutiodon" teeth have a very thin (2-3 $\mu \mathrm{m})$ BUL, with poor- to well-defined columnar enamel emanating towards the OES from the BUL (Figure 6C-D). Measurable columns are 13-28 $\mu \mathrm{m}$ in width and are visible in transverse (NCSM 23303), longitudinal (NCSM 24322B), and tangential (NCSM 24322A) sections (Figure 6A-D). The most striking feature evident in "Rutiodon" teeth are the numerous, well-defined LIGs present in all sampled teeth and in every plane of sectioning (Figure $6 \mathrm{~A}-\mathrm{F}$, not all labeled due to sheer number). The LIGs are consistent throughout the thickness of the enamel and are typically spaced 2-5 $\mu \mathrm{m}$ apart (Figure 6A-F). These numerous LIGs give the appearance of wavy enamel (e.g., Sander, 1999 and Whitney and Sidor, 2019), however, we interpret "Rutiodon" as possessing columnar, rather than wavy enamel (see Discussion).

\section{Revueltian-Machaeroprosopus}

Enamel thicknesses for Machaeroprosopus teeth range from $45-60 \mu \mathrm{m}$ in the type $U$ tooth (Figure 7A-C), 43-87 $\mu \mathrm{m}$ (Figure 7D-F) and 24$29 \mu \mathrm{m}$ in the type I teeth (NMMNH P-33105 and NMMNH P-33593, respectively), and 47-109 $\mu \mathrm{m}$ in the type B tooth. Interestingly, the fluting visible on the outer surface of type $U$ tooth NMMNH P-33105 is made up entirely of enamel, with no contribution from the underlying dentine (Figure 7C), unlike in Smilosuchus.

Most of the Machaeroprosopus teeth appear to lack a BUL, though NMMNH P-33105 possesses a thin $(<5 \mu \mathrm{m})$, poorly-defined BUL (Figure $7 \mathrm{~B})$. The enamel is composed of well-defined columnar crystallite packages 7-20 $\mu \mathrm{m}$ thick (Figure 7F). There may be three to four LIGs present near the middle of the enamel of NMMNH P-33103 (Figure 7B).

\section{Apachean-Redondasaurus}

Enamel thickness of type I teeth of Redondasaurus ranges from 18-39 $\mu \mathrm{m}$ (Figure 8A) on NMMNH P-36184. Only one site on NMMNH P- 
36185 could be measured, where thickness ranged from 52-55 $\mu \mathrm{m}$ (Figure 8B). The type B tooth (NMMNH P-36186) possessed the thickest enamel, with thicknesses of 90-109 $\mu \mathrm{m}$, with the greatest thickness at the denticles.

Redondasaurus teeth possess a very thin (2$3 \mu \mathrm{m})$, well-developed BUL from which columnar enamel emerges (Figure 8B). Column thickness varies from 16-38 $\mu \mathrm{m}$ in the type $B$ tooth (Figure $8 \mathrm{E})$. These well-defined columnar packages are visible in both transverse and tangential sections (Figure 8E-F). Only one of the sampled Redondasaurus teeth contained any discernable LIGs (NMMNH P-36184, Figure 8A) and, like Angistorhinus, these few LIGs were near the OES.

\section{Statistical Analyses}

While tooth EM features appears to be conservative between phytosaur genera, with the notable exception of "Rutiodon", the thickness of enamel varies among tooth types and genera. The ANOVA results show significant between group variation in enamel thickness $(\mathrm{df}=2, \mathrm{~F}=7.187, \mathrm{p}=$ 0.001). Type $B$ teeth were significantly thicker than type $U$ and I teeth in post hoc analysis, with a greater average thickness of $\sim 14 \mu \mathrm{m}$ and $\sim 10 \mu \mathrm{m}$ (B vs. $U p=0.001$ and $B$ vs. I $p=0.004$ ) (Figure $9 A)$. There was not a significant difference in the enamel thicknesses of $U$ and I teeth $(p=0.417)$. When we controlled for size (Figure 9B) ANOVA results again show significant between group variation in enamel thickness ( $\mathrm{df}=2, \mathrm{~F}=14.3, \mathrm{p}<$ 0.001 ), type $B$ teeth were still thicker in enamel by crown height $(\mathrm{CH})$ from type $U$ by $0.6 \mu \mathrm{m}$ per $\mathrm{mm}$ $(p=0.003)$ and type I by $1.1 \mu \mathrm{m}$ per $\mathrm{mm}(\mathrm{p}<$ $0.001)$, and the difference between $U$ and $I$ teeth became significant $(p=0.02)$, with $U$ teeth possessing thicker enamel (approximately $0.5 \mu \mathrm{m}$ per $\mathrm{mm} \mathrm{CH}$ ). In analyzing the thicknesses from transverse sections of all types of teeth from each taxon ANOVA found that enamel thickness does differ significantly between taxa ( $d f=7, F=2.083, p$ $=0.048$ ) but without a visually discernible trend through time (Figure 9C). We then controlled for tooth type and limited our comparison to type I teeth as we had the most samples of type I across the most taxa. In type I teeth average enamel thickness appears to thin through time upon visual inspection (Figure 9D); Angistorhinus has the thickest type I teeth (mean $=89.9 \mu \mathrm{m})$ and Machaeroprosopus the thinnest (mean $=41.6 \mu \mathrm{m}$ ). However, when we controlled for tooth size, this visual pattern reversed and enamel thickness by crown height appears to increase through time (Figure
9E). Angistorhinus had the thinnest enamel (1.9 $\mu \mathrm{m}$ per $\mathrm{mm} \mathrm{CH}$ ) and Machaeroprosopus had the thickest $(5.9 \mu \mathrm{m}$ per $\mathrm{mm} \mathrm{CH})$. We were unable to include Redondasaurus in the size-controlled analysis as the tooth crowns were fragmentary preventing an accurate measure of crown height.

\section{DISCUSSION}

The primary focus of this study was to expand upon the variation of phytosaur tooth enamel recorded by Sander (1999), and then evaluate the use of tooth EM in taxonomic assignment of isolated phytosaur teeth. Much like the indeterminate phytosaur from Switzerland (Sander, 1999), all of the sampled phytosaur teeth consisted of entirely columnar enamel with well-defined boundaries and polygonal cross-sections visible in tangential sections (Figure 4B, Figure 7F, Figure 8C), and columns typically $10-20 \mu \mathrm{m}$ wide. We were, however, unable to document additional instances of thin $(\sim 20 \mu \mathrm{m})$ entirely parallel enamel, as reported in two of the indeterminate phytosaurs of the Dockum Group in Texas (Sander, 1999). Also, unlike Sander's (1999) study, we did not uncover significant variation between phytosaur teeth from the same localities, or even the same basins. As the phytosaur teeth originally used in Sander (1999) were unavailable for us to examine (Sander, personal commun., 2015), we cannot reevaluate their assignment to Phytosauria, though the distinct possibility exists that the teeth with thin, parallel enamel belong to a different clade. We consider it possible that the outlier tooth may in fact represent a doswelliid, a clade not reported from the Dockum in the 1990s, not widely known until relatively recently, and whose tooth enamel microstructure has not been studied (e.g., Sues et al., 2013). It is also possible that the thin parallel enamel belongs to a homodont phytosaur, such as Parasuchus (=Paleorhinus), an indeterminate homodont phytosaur is known from the Otischalkian of West Texas, in addition to the heterodont Angistorhinus (e.g., Lucas et al., 1993).

Following the design of this study, two new taxa were described from the Sonsela Member, Chinle Formation in the Petrified Forest National Park, Pravusuchus hortus Stocker 2010 and Protome batalaria Stocker 2012. Based on stratigraphic position and correlation, these new taxa are likely stratigraphically higher than the Bluewater Creek and Blue Mesa Members of L-3380 and L-6818, respectively. These species are thus far only known from their type specimens, and the Chinle Formation has been well-sampled for phyto- 

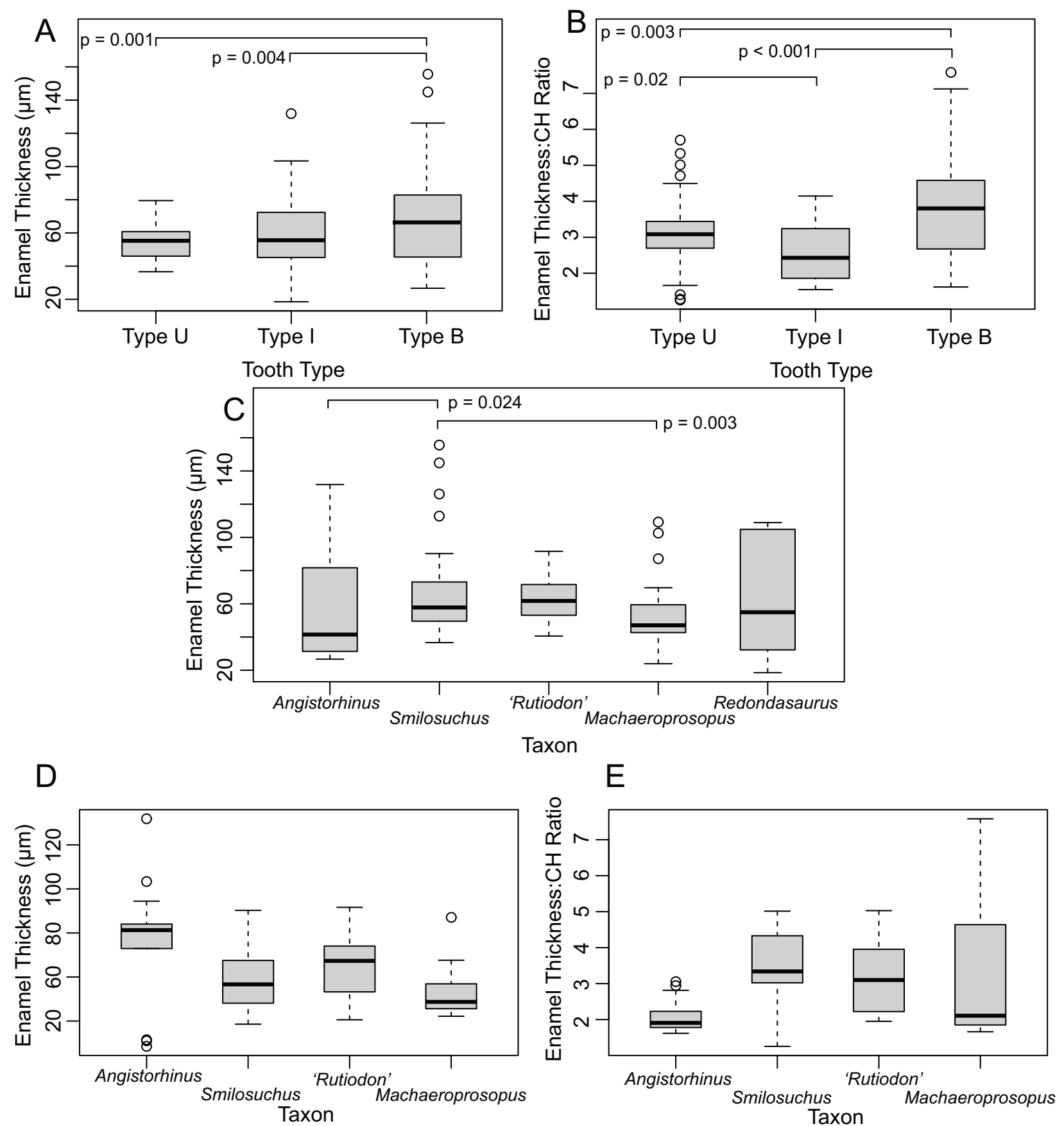

FIGURE 9. Boxplots of overall enamel thickness and enamel thickness to crown height ratio. Circles around boxplots represent outliers. 9A-Enamel thickness $(\mu \mathrm{m})$ by tooth type. Type B teeth have the thickest enamel on average; 9BEnamel thickness $(\mu \mathrm{m})$ over crown height $(\mathrm{mm})$ by tooth type. We included this ratio as a way to account for the overall size of teeth. Type B teeth have the thickest enamel on average, followed by type U; $9 \mathrm{C}$-Enamel thickness ( $\mu \mathrm{m})$ of transverse sections by taxonomic assignment with stratigraphically oldest on the left of the plot,showing variation in enamel thickness but no chronological trend; 9D-Enamel thickness $(\mu \mathrm{m})$ of transverse sections of type I teeth. When only considering type I teeth enamel thickness thins through time; 9E-Enamel thickness ( $\mu \mathrm{m})$ over crown height $(\mathrm{mm})$ of transverse sections of type I teeth. When overall tooth size is accounted for, the opposite of Figure 9E is seen with typical enamel per $\mathrm{mm}$ height increasing through time. 
saur taxa, so, their rarity renders them even less likely to be present in our sample at the stratigraphically lower intervals.

The consistency of the heterodont tooth EM within and between the western USA phytosaurs indicates that phytosaur EM has little use in taxonomic identification-at least to genus level-and is therefore not useful as a biostratigraphic marker. The only difference we saw was in the contribution of the dentine to the carina in Type $U$ teeth in Smilosuchus but not in Machaeroprosopus, but suspect that this trait, while worth studying further, may be variable. However, we did find distinct differences between phytosaurs of different basins. Few of the western USA phytosaurs possess LIGs, and in those taxa the individual LIGs are not especially well-developed. In contrast, the Newark Supergroup phytosaur, "Rutiodon", preserves numerous, well-defined LIGs throughout all the sampled teeth (Figure 6A-F). It has been argued that North American phytosaur genera had a continuous range from the Newark Supergroup into the western USA, and that "Rutiodon" is synonymous with Angistorhinus (Hungerbühler and Sues, 2001) or Smilosuchus/Leptosuchus (Hunt, 1989). The differences in schmelzmuster between the sampled Newark Supergroup and western USA phytosaurs instead supports the hypothesis that the taxa in these basins are phylogenetically distinct, and there existed at least two separate populations of phytosaurs in North America during the Late Triassic. This finding of larger scale differences in schmelzmuster than the generic level is an echo of previous findings related to dinosaur phylogenetics, in which tooth EM is found to be useful in distinguishing dinosaurs only at the suprageneric clade level (Hwang, 2011). An important caveat in this assessment is the variable appearance of LIGs due to specimen preparation. We attempted to minimize variability in LIGs appearance by standardizing the etching process and taking sections from multiple directions. Because strong LIGs are present in transverse, longitudinal, and tangential sections we believe this is an authentic signal of the enamel at not an artifact of a slightly different etch, but that remains a possibility.

The differential occurrence of LIGs in phytosaurs implies variable enamel deposition within Phytosauria. If LIGs do represent daily arrests in growth due to autonomic nervous system activity (Appenzeller et al., 2005), then one of two scenarios for "Rutiodon" enamel deposition is possible. Either "Rutiodon" replaces and grows its teeth at a significantly slower rate than other phytosaurs, thereby recording numerous LIGs, or "Rutiodon" deposits enamel in a far more cyclical manner than other phytosaurs, which deposit enamel fairly continuously, resulting in few to no LIGs. We favor the latter hypothesis, as it requires only a change in the timing of enamel deposition, rather than a physiological shift. We have no additional lines of evidence suggesting Newark phytosaurs had significantly higher growth rates. Additionally, the western North American phytosaurs were all recovered from units interpreted to represent semi-arid to fluvial deposition (High Jr. et al., 1969; Heckert and Lucas, 2003; Tanner et al., 2003; Cleveland et al., 2007; Trendell et al., 2013) with the exception of Redondosaurus, as the Redonda Formation is interpreted as a mosaic of lakes (Hester et al., 2001; Lucas et al., 2006) whereas the "Rutiodon" teeth are found in lacustrine environments (Litwin and Ash, 1993). Therefore, this different enamel deposition pattern could be the result of environmental controls. Though the latter hypothesis seems more plausible, to test both hypotheses would require a comprehensive study of tooth replacement in phytosaurs using complete jaws with in situ teeth. Sander (1999, pl. 9f) illustrated a single tooth referred to an indeterminate rauisuchid that possesses columnar enamel with many welldeveloped LIGs throughout the enamel that strongly resembles our own images of Rutiodon, perhaps indicating some convergence. An alternate explanation for the features of "Rutiodon" teeth is that they are composed of wavy enamel. In wavy enamel crystallites are in a staggered arrangement with a constant gradual angle away from the EDJ (Sander, 1999). As a result of the helical arrangement of the crystallites numerous differentially reflective waves are formed through the enamel giving a similar appearance to LIGs, and can be seen in ornithischian dinosaurs (Sander, 1999; Hwang 2010; 2011) and in a tapinocephalid synapsid (Whitney and Sidor, 2019). If this were the case, it would mean "Rutiodon" teeth likely reflect a drastically different diet or feeding mode as wavy enamel is associated with herbivores and a grinding style of eating and would be the first occurrence of wavy enamel in Pseudosuchia. However, we do not believe "Rutiodon" teeth possess wavy enamel due to the presence of diverging zones in the center of columns and converging zones at the edges of columns, which indicate different angles in crystallite structure not expected in wavy enamel. These columns are also apparent in bundles in tangential view (Figure 6C), typical of columnar enamel, not wavy enamel 
(Sander, 1999). Given that columnar and wavy enamel both appear in hadrosaur ornithischian and wavy enamel is still poorly understood, it is possible that they represent a continuum of enamel types, rather than distinct types, but based off Sander (1999) interpretations of enamel types "Rutiodon" teeth are more similar to columnar enamel.

Different types of heterodont phytosaur teeth do preserve predictable patterns, chiefly with regards to enamel thickness. The type $B$, or bladelike, teeth consistently form the thickest enamel, even when overall tooth size is accounted for in our analyses. This discovery reinforces the idea that some phytosaurs have "true heterodont" or tripartite dentition (Hungerbühler, 2002). Columnar enamel is thought to be more resistant to fracturing and bending (Sander, 1999). This, combined with the overall thicker enamel of type B teeth, lends credence to the hypothesis that the posterior maxillary (type B) teeth were primarily responsible for food processing, by way of slicing and shearing soft tissue, in phytosaurs (Hungerbühler, 2002). This would parallel the role of carnassial teeth in carnivoran mammals, another heterodont predatory clade with blade-shaped teeth in the back of the jaw, although in carnivorans the carnassial teeth function with tooth-tooth occlusion, not evidenced in phytosaurs (Greaves, 1983). However, recent tooth enamel microwear analysis of phytosaurs did not find evidence of material processing differences for teeth in different sections of the jaw (Bestwick et al., 2021). Instead, the differences between the posterior (type $\mathrm{B}$ ) and the anterior + middle teeth (types $\mathrm{C}, \mathrm{I}, \mathrm{U}$ ) are hypothesized to be the result of differential forces during food processing, potentially by side-to-side shaking of the head or the "death roll" of extant crocodylians (Bestwick et al., 2021), though those authors also note that these ideas have not been explicitly tested in phytosaurs. A simpler explanation is that the Type B teeth experience greater pressure, generating greater bite force, than more anterior teeth since jaws are Type 3 levers with Type B teeth closer to the fulcrum. Thus, they need more reinforcement in the form of thicker enamel. This is in line with gross morphological examinations of rear teeth in durophagous animals, which need to take bite forces to an extreme (see Miller-Camp, 2016).

Although tooth schmelzmuster in phytosaurs is not useful for taxonomic assignment and therefore biostratigraphy, EM does provide useful insights into biogeographic distributions and ecology of phytosaurs. Using EM, we identify eastern and western North American phytosaurs as two distinct populations not only phylogenetically, but physiologically and potentially ecologically. This study of EM is also one of the few to statistically compare enamel thickness, whereas most previous work has relied upon relative comparisons. Our finding of significant patterns in opposite directions when tooth size is controlled for points to the importance of including measurements of all teeth prior to destructive sampling, and including the macroscopic measurements to contextualize EM observations, as highlighted by Hwang (2011), Heckert and Miller-Camp (2013), and Wang et al. (2015). Future studies of EM should continue to use more objective methods when comparing enamel within and between taxa. We echo the conclusions of other authors (e.g., Sander, 1999; Hwang, 2011; Heckert and Miller-Camp, 2013; Button et al., 2017) in emphasizing the potential of tooth EM to address questions of evolution, diet, and distribution, particularly for archosauriforms. Because phytosaurs have a nearly Pangean distribution, and their shed teeth are one of the most common body fossils found in a variety of basins of Late Triassic age, we encourage workers to section some of these teeth to elucidate additional details of phytosaur tooth EM, and thus possible ecological and taxonomic variation.

\section{CONCLUSIONS}

We present the first systematic sampling of phytosaur tooth enamel microstructure, sampling throughout the Late Triassic of North America. Phytosaur EM features appear to be highly conservative through time with some changes in overall enamel thickness, but a distinct change across basins with phytosaur EM from eastern North America (i.e., Newark Supergroup) preserving $>30$ LIGs per tooth. This demonstrates that phytosaurs from eastern and western North America deposited enamel in a visibly different manner and lends support to the hypothesis that phytosaurs are taxonomically distinct in eastern and western North America.

Given the differences between phytosaur EM of major geographic regions and apparent conservation of EM through time ( $15 \mathrm{my})$ within a single region, a potentially fruitful area of future work would be to examine phytosaur EM from other regions, ideally those with multiple time intervals that preserve phytosaurs. A single tooth from an indeterminate phytosaur of Hallau, Switzerland, was sectioned by Sander (1999) and possessed EM similar to that of the western North American 
phytosaurs in this study (i.e., rare LIGs, columnar enamel $\sim 60 \mu \mathrm{m}$ thick). However, there remain taxonomic and biogeographic questions about phytosaurs that could be investigated using phytosaur tooth EM, namely the potential biogeographic connectedness of the less sampled African and Indian phytosaurs to contemporaneous European phytosaurs and the taxonomic monophyly of genera such as Paleorhinus and Machaeroprosopus (Stocker and Butler, 2013; Jones and Butler, 2018). Another potential avenue of research would be to compare growth between eastern and western North American phytosaurs using additional skeletal elements. Our tooth EM results suggest the eastern phytosaurs of the Newark Supergroup deposited enamel during tooth development unique from the western phytosaurs of the Chinle/ Dockum strata. As annual growth records are wellpreserved in phytosaur elements such as osteoderms (e.g., Scheyer et al., 2014), a comparison of elements from temporally-equivalent phytosaurs could elucidate if the variation in EM LIGs is the result of a novel growth strategy in Newark Supergroup phytosaurs, or limited to a change in tooth replacement and growth.

Phytosaurs are often reconstructed as semiaquatic predators with variation in dietary specialization based upon overall skull morphology (Hunt, 1989) and heterodont dentition (Hungerbühler, 2000; Datta et al., 2020; Bestwick et al., 2021). It was not until recently that these hypotheses have been explicitly tested. Our finding that type B, or the posterior maxillary teeth, have thicker than average enamel, even when controlling for size, supports the hypothesis that different teeth in heterodont phytosaurs performed different functions. This, along with phytosaur tooth enamel microwear results (e.g., Bestwick et al., 2021) suggest posterior maxillary teeth (type B) were under a different pressure regime during feeding. The combination of tooth EM description and quantification com- bined with other methods of dietary interpretation like dentine ultrastructure (e.g., Brink et al., 2016), enamel microwear (e.g., Bestwick et al., 2021), and 3D-OPCR (e.g., Melstrom, 2017) is a promising method of testing dietary reconstructions of extinct saurians. This is particularly important within the context of the archosauriform radiation following the end-Permian mass extinction, when archosauriforms evolved to fill a variety of ecological roles after the decline of parareptiles and non-mammalian therapsids (Nesbitt, 2011; Ezcurra, 2016; Ezcurra and Butler, 2018). By combining independent measures of food processing, we can use the diversity of EM in reptiles (e.g., Sander, 1999) to better reconstruct how archosauriforms rose to ecological dominance in the Triassic.

\section{ACKNOWLEDGMENTS}

This work builds upon the senior undergraduate thesis of J. Miller-Camp, which was supported in part by the Office of Student Research (OSR) at Appalachian State University (ASU). Work by both JM-C and DKH at Appalachian were supported by Undergraduate Research Assistantships from the Department of Geological and Environmental Sciences at ASU. Travel grants from OSR and the department supported student travel for presentations related to this project. The College of Arts and Sciences at ASU provided nearly unlimited access to the SEM facility with technical support from G. Hou and S.J. Hageman. Discussions with S.H. Hwang, P.M. Sander, and M.R. Stocker and reviews by M.R. Whitney and J. Bestwick improved the manuscript. Teeth from NMMNH localities 582, 3380,3845 , and 4211 , were initially sectioned by K. Stokosa. Department of Geological and Environmental Sciences laboratories manager A. Love assisted with specimen preparation of these and the specimens from NMMNH locality 6018 and NCPaleo 0401.

\section{REFERENCES}

Abramoff, M.D., Magalhaes, P.J., and Ram, S.J. 2004. Image Processing with ImageJ. Biophotonics International, 11:36-42.

Appenzeller, O., Gunga, H.-C., Qualls, C., Furlan, R., Porta, A., Lucas, S.G., Heckert, A.B., Kirsch, K., Costa-Junqueira, M.A., Guillén, S.E., Sander, M., Schneider, T., and Blottner, B. 2005. A hypothesis: autonomic rhythms are reflected in growth lines of teeth in humans and extinct archosaurs. Autonomic Neuroscience: Basic and Clinical, 117:115-119. https://doi.org/10.1016/j.autneu.2004.10.003 
Ballew, K.L. 1989. A phylogenetic analysis of Phytosauria from the Late Triassic of the western United States, p. 309-339. In Lucas, S.G. and Hunt, A.P. (eds.), Dawn of the Age of Dinosaurs in the American Southwest. New Mexico Museum of Natural History, Albuquerque.

Bestwick, J., Jones, A.S., Purnell, M.A., and Butler, R.J. 2021. Dietary constraints of phytosaurian reptiles revealed by dental microwear textural analysis. Palaeontology, 64:1-18. https://doi.org/10.1111/pala.12515

Brink, K.S., Reisz, R.R., LeBlanc, A.R.H., Chang, R.S., Lee, Y.C., Chiang, C.C., Huang, T., and Evans, D.C. 2015. Developmental and evolutionary novelty in the serrated teeth of theropod dinosaurs. Scientific Reports, 5:12338. https://doi.org/10.1038/srep12338

Brink, K.S., Chen, Y.-C., Wu, Y.-N., Liu, W.-M., Shieh, D.-B., Huang, T.D., Sun, C.-K., and Reisz, R.R. 2016. Dietary adaptions in the ultrastructure of dinosaur dentine. Journal of The Royal Society Interface, 13:20160626. https://doi.org/10.1098/rsif.2016.0626

Brochu, C.A. 2001. Progress and future directions in archosaur phylogenetics. Journal of Paleontology, 75(6):1185-1201. https://doi.org/10.1017/S0022336000017236

Bromage, T.G. and Dean, M.C. 1985. Re-evaluation of the age at death of immature fossil hominids. Nature, 317:525-527. https://doi.org/10.1038/317525a0

Brusatte, S.L., Butler, R.J., Niedźwiedzki, G., Sulej, T., Bronowicz, R., and Satkunas, J. 2012. First record of Mesozoic terrestrial vertebrates from Lithuania: phytosaurs (Diapsida: Archosauriformes) of probable Late Triassic age, with a review of phytosaur biogeography. Geological Magazine, 150:110-122. https://doi.org/10.1017/S0016756812000428

Buffetaut, E., Dauphin, Y., Jaeger, J., Martin, M., Mazin, J., and Tong, H. 1986. Prismatic dental enamel in theropod dinosaurs. Naturwissenschaften, 73:326-327. https://doi.org/10.1007/BF00451481

Button, K., You, H., Kirkland, J.I., and Zanno, L. 2017. Incremental growth of therizinosaurian dental tissues: implications for dietary transitions in Theropoda. PeerJ, 5:e4129. https://doi.org/10.7717/peerj.4129

Camp, C.L. 1930. A study of the phytosaurs: with description of new material from western North America. Memoirs of the University of California, 10:1-161.

Camp, J.A. 2007. Enamel microstructure in phytosaurs and its implications for phylogeny, ecology, and biostratigraphy. Unpublished undergraduate honors thesis. Appalachian State University.

Camp, J.A. and Heckert, A.B. 2007. Tooth enamel microstructure in Phytosauria (Reptilia: Archosauria) and its implications for phylogeny, ecology, and biostratigraphy. Geological Society of America Abstracts with Programs, 39(2):86.

Chatterjee, S. 1978. A primitive parasuchid (phytosaur) reptile from the Upper Triassic Maleri Formation of India. Palaeontology, 21:83-127.

Chatterjee, S. 1980. Malerisaurus, a new eosuchian reptile from the Late Triassic of India. Philosophical Transactions of the Royal Society of London, B, 291:163-200. https://doi.org/10.1098/rstb.1980.0131

Chen, J., LeBlanc, A.R.H., Jin, L., Huang, T., and Reisz, R.R. 2018. Tooth development, histology, and enamel microstructure in Changchunsaurus parvus: Implications for dental evolution in ornithopod dinosaurs. PLoS ONE, 13:e0205206. https://doi.org/10.1371/journal.pone.0205206

Cleveland, D.M., Atchley, S.C., and Nordt, L.C. 2007. Continental sequence stratigraphy of the Upper Triassic (Norian-Rhaetian) Chinle strata, northern New Mexico, USA: allocyclic and autocyclic origins of paleosol-bearing alluvial successions. Journal of Sedimentary Research, 77:909-924. https://doi.org/10.2110/jsr.2007.082

Colbert, E.H., Brown, B., Bird, R.T., and Matthew, W.D. 1947. Studies of the phytosaurs Machaeroprosopus and Rutiodon. Bulletin of the American Museum of Natural History, 88:53-96. https://doi.org/10.1086/396106

Colbert, E.H. and Gregory, J.T. 1957. Correlation of continental Triassic sediments by vertebrate fossils. Geological Society of America Bulletin, 68:1456-1467. https://doi.org/10.1130/0016-7606(1957)68[1451:COTTFO]2.0.CO;2

Cope, E.D. 1881. Belodon in New Mexico. The American Naturalist, 15:921-924. https://doi.org/10.1086/272963 
Datta, D., Ray, S., and Bandyopadhyay, S. 2019. Cranial morphology of a new phytosaur (Diapsida, Archosauria) from the Upper Triassic of India: implications for phytosaur phylogeny and biostratigraphy. Papers in Palaeontology, 7:675-708. https://doi.org/10.1002/spp2.1292

D'Amore, D.C., Harmon, M., Drumheller, S.K., and Testin, J.J. 2019. Quantitative heterodonty in Crocodylia: assessing size and shape across modern and extinct taxa. PeerJ, 7, e6485. https://doi.org/10.7717/peerj.6485

Datta, D., Sharma, K., and Ray, S. 2020. Cranial evolution of the Late Triassic phytosaurs (Diapsida, Archosauria): preliminary observations from landmark-based morphometric analysis. Historical Biology, 1-23. https://doi.org/10.1080/08912963.2020.1822831

Datta, D., Kumar, N., and Ray, S. 2021. Taxonomic identification of isolated phytosaur (Diapsida, Archosauria) teeth from the Upper Triassic of India and their significances. Historical Biology, 33:272-282. https://doi.org/10.1080/08912963.2019.1613652

Emmons, E. 1856. Geological Report on the Midland Counties of North Carolina. George P. Putnam, Raleigh. https://doi.org/10.5962/bhl.title.34269

Ezcurra, M.D. 2016. The phylogenetic relationships of basal archosauromorphs, with an emphasis on the systematics of proterosuchian archosauriforms. PeerJ, 4, e1778. https://doi.org/10.7717/peerj.1778

Ezcurra, M.D. and Butler, R.J. 2018. The rise of the ruling reptiles and ecosystem recovery from the Permo-Triassic mass extinction. Proceedings of the Royal Society B, 285:20180361. https://doi.org/10.1098/rspb.2018.0361

Greaves, W.S. 1983. A functional analysis of carnassial biting. Biological Journal of the Linnean Society, 20:353-363. https://doi.org/10.1111/j.1095-8312.1983.tb01596.x

Gregory, J.T. 1962. The relationships of the American phytosaur Rutiodon. American Museum Novitates, 2095:1-22. http://hdl.handle.net/2246/3397

Gozzi, E. and Renesto, S. 2003. A complete specimen of Mystriosuchus (Reptilia, Phytosauria) from the Norian (Late Triassic) of Lombardy (Northern Italy). Rivista Italiana di Paleontologia e Stratigrafia, 109:475-498. https://doi.org/10.13130/2039-4942/5518

Heckert, A.B. 1999. Upper Triassic tetrapods from the Lucero uplift, central New Mexico. New Mexico Geological Society Guidebook, 50:311-315.

Heckert, A.B., Lucas, S.G., Hunt, A.P., and Harris, J.D. 2001. A giant phytosaur (Reptilia: Archosauria) skull from the Redonda Formation (Upper Triassic: Apachean) of east-central New Mexico. New Mexico Geological Society Guidebook, 52:171-178.

Heckert, A.B. and Lucas, S.G. 2003. Stratigraphy and paleontology of the lower Chinle Group (Adamanian: latest Carnian) in the vicinity of St. Johns, Arizona. New Mexico Geological Society Guidebook, 54:281-288.

Heckert, A.B., Lucas, S.G. and Hunt, A.P. 2005. Triassic vertebrate fossils in Arizona. New Mexico Museum of Natural History and Science Bulletin, 29:16-44.

Heckert, A.B., Lucas, S.G., Dickinson, W.R., and Mortensen, J.K. 2009. New ID-TIMS U-Pb ages for Chinle Group strata (Upper Triassic) in New Mexico and Arizona, correlation to the Newark Supergroup, and implications for the "long Norian". Geological Society of America Abstracts with Programs, 41:123.

Heckert, A.B., Mitchell, J.S., Schneider, V.P., and Olsen, P.E. 2012. Diverse new microvertebrate assemblage from the Upper Triassic Cumnock Formation, Sanford Subbasin, North Carolina, USA. Journal of Paleontology, 86:368-390. https://doi.org/10.1666/11-098.1

Heckert, A.B. and Miller-Camp, J.A. 2013. Tooth enamel microstructure of Revueltosaurus and Krzyzanowskisaurus (Reptilia:Archosauria) from the Upper Triassic Chinle Group, USA: Implications for function, growth, and phylogeny. Palaeontologia Electronica, 16.1.1A:123. https://doi.org/10.26879/319

Hester, P.M., Lucas, S.G., and Ulmer-Scholle, D. 2001. Lacustrine depositional environments of the Upper Triassic Redonda Formation, east-central New Mexico. New Mexico Geological Society Guidebook, 52:153-168.

High, Jr., L.R., Hepp, D.M., Clark, T., and Picard, M.D. 1969. Stratigraphy of Popo Agie Formation (Late Triassic), Uinta Mountain area, Utah and Colorado. Geologic Guidebook of the Uinta Mountains: Utah's Maverick Range, Sixteenth Annual Field Conference, p. 181192.

Huene, F. 1922. Beitrdäge zur Kenntnis der Parasuchier. Jahrbuch der Preussischen Geologischen Landesanstalt, 42:59-160. 
Hungerbühler, A. 2000. Heterodonty in the European phytosaur Nicrosaurus kapffi and its implications for the taxonomic utility and functional morphology of phytosaur dentitions. Journal of Vertebrate Paleontology, 20:31-48. https://doi.org/10.1671/0272-4634(2000)020[0031:HITEPN]2.0.CO;2

Hungerbühler, A. 2002. The Late Triassic phytosaur Mystriosuchus westphali, with a revision of the genus. Palaeontology, 45:377-418. https://doi.org/10.1111/1475-4983.00242

Hungerbühler, A. and Sues, H.-D. 2001. Status and phylogenetic relationships of the Late Triassic phytosaur Rutiodon carolinensis. Journal of Vertebrate Paleontology, 21(Suppl. 3):64A. https://doi.org/10.1080/02724634.2001.10010852

Hungerbühler, A., Mueller, B., Chatterjee, S., and Cunningham, D.P. 2013. Cranial anatomy of the Late Triassic phytosaur Machaeroprosopus, with the description of a new species from West Texas. Earth and Environmental Science Transactions of the Royal Society of Edinburgh, 103(3-4):269-312. https://doi.org/10.1017/S1755691013000364

Hunt, A.P. 1989. Cranial morphology and ecology among phytosaurs, p. 349-354. In Lucas, S.G. and Hunt, A.P. (eds.), Dawn of the Age of Dinosaurs in the American Southwest. New Mexico Museum of Natural History, Albuquerque.

Hunt, A.P. and Lucas, S.G. 1989. New genotype designations for the phytosaurs Mystriosuchus and Rutiodon with a discussion of the taxonomic status of Mystriosuchus, Clepsysaurus and Rutiodon. In Lucas, S.G. and Hunt, A.P. (eds.), Dawn of the Age of Dinosaurs in the American Southwest. New Mexico Museum of Natural History, Albuquerque. 340-348.

Hunt, A.P. and Lucas, S.G. 1991. The Paleorhinus biochron and the correlation of the nonmarine Upper Triassic of Pangaea. Palaeontology, 34:487-501.

Hunt, A.P., Lucas, S.G., and Heckert, A.B. 2005. Definition and correlation of the Lamyan: A new biochronological unit for the nonmarine Late Carnian (Late Triassic). New Mexico Geological Society Guidebook, 56:357-366.

Hwang, S.H. 2005. Phylogenetic patterns of enamel microstructure in dinosaur teeth. Journal of Morphology, 266:208-240. https://doi.org/10.1002/jmor.10372

Hwang, S.H. 2010. The utility of tooth enamel microstructure in identifying isolated dinosaur teeth. Lethaia, 43:307-322. https://doi.org/10.1111/j.1502-3931.2009.00194.x

Hwang, S.H. 2011. The evolution of dinosaur tooth enamel microstructure. Biological Reviews, 86:183-216. https://doi.org/10.1111/j.1469-185x.2010.00142.x

Irmis, R.B. 2005. The vertebrate fauna of the Upper Triassic Chinle Formation in northern Arizona. Mesa Southwest Museum Bulletin, 9:63-88.

Irmis, R.B., Mundil, R., Martz, J.W., and Parker, W.G. 2011. High-resolution U-Pb ages from the Upper Triassic Chinle Formation (New Mexico, USA) support a diachronous rise of dinosaurs. Earth and Planetary Science Letters, 309:258-267. https://doi.org/10.1016/j.epsl.2011.07.015

Johnston, P.A. 1979. Growth rings in dinosaur teeth. Nature, 278:635-636. https://doi.org/10.1038/278635a0

Jones, A.S. and Butler, R.J. 2018. A new phylogenetic analysis of Phytosauria (Archosauria: Pseudosuchia) with the application of continuous and geometric morphometric character coding. PeerJ, 6:e5901. https://doi.org/10.7717/peerj.5901

Kammerer, C.F., Butler, R.J., Saswati, B., and Stocker, M.R. 2016. Relationships of the Indian phytosaur Parasuchus hislopi Lydekker, 1885. Papers in Palaeontology, 2:1-23. https://doi.org/10.1002/spp2.1022

Koenigswald, W. and Sander, P.M. 1997. Glossary of terms used for enamel microstructures, p. 267-280. In Koenigswald, W. and Sander, P.M. (eds.), Tooth Enamel Microstructure. Rotterdam, Balkem. https://doi.org/10.1201/9781003077930-15

Litwin, R.J. and Ash, S.R. 1993. Revision of the biostratigraphy of the Chatham Group (Upper Triassic), Deep River Basin, North Carolina, USA. Review of Palaeobotany and Palynology, 77:75-95. https://doi.org/10.1016/0034-6667(93)90057-2

Long, R.A. and Murry, P.A. 1995. Late Triassic (Carnian and Norian) tetrapods from the southwestern United States. Bulletin of the New Mexico Museum of Natural History and Science, 4:1-254.

Lucas, S.G. 1994. The beginning of the age of dinosaurs in Wyoming. Wyoming Geological Association Guidebook, 44:105-113.

Lucas, S.G. 1998. Global Triassic tetrapod biostratigraphy and biochronology. Palaeogeography, Palaeoclimatology, Palaeoecology, 143:347-384. https://doi.org/10.1016/S0031-0182(98)00117-5 
Lucas, S.G. and Hunt, A.P. 1993. Tetrapod biochronology of the Chinle Group (Upper Triassic), Western United States. Bulletin of the New Mexico Museum of Natural History and Science, 3:327-329.

Lucas, S.G., Hunt, A.P., and Kahle, R. 1993. Late Triassic vertebrates from the Dockum Formation near Otis Chalk, Howard County, Texas. New Mexico Geological Society Guidebook, 44:237-244.

Lucas, S.G. and Heckert, A.B. 1994. Triassic stratigraphy in the Lucero uplift, Cibola, Valencia and Socorro counties, New Mexico. New Mexico Geological Society Guidebook, 45:241-254.

Lucas, S.G., Heckert, A.B., and Hotton, III, N. 2002. The rhynchosaur Hyperodapedon from the Upper Triassic of Wyoming and its global biochronological significance. Bulletin of the New Mexico Museum of Natural History and Science, 21:149-156.

Lucas, S.G., Spielmann, J.A., and Hunt, A.P. 2006. Lithostratigraphic subdivision of the Redonda Formation of the Chinle Group, Upper Triassic of east-central New Mexico. New Mexico Museum of Natural History and Science Bulletin, 37:62-66.

Lucas, S.G. and Tanner, L.H. 2007. Tetrapod biostratigraphy and biochronology of the TriassicJurassic transition on the southern Colorado Plateau, USA. Palaeogeography, Palaeoclimatology, Palaeoecology, 244:242-256. https://doi.org/10.1016/j.palaeo.2006.06.030

Lucas, S.G., Heckert, A.B., and Rinehart, L.F. 2007. A giant skull, ontogenetic variation and taxonomic validity of the Late Triassic phytosaur Parasuchus. New Mexico Museum of Natural History and Science Bulletin, 41:219-221.

Mao, F.Y., Wang, Y.Q., Bi, S.D., Guan, J., and Meng, J. 2017. Tooth enamel microstructures of three Jurassic euharamiyidans and implications for tooth enamel evolution in allotherian mammals. Journal of Vertebrate Paleontology, 37:e1279168. https://doi.org/10.1080/02724634.2017.1279168

Marsh, A.D., Parker, W.G., Stockli, D.F., and Martz, J.W. 2019. Regional correlation of the Sonsela Member (Upper Triassic Chinle Formation) and detrital U-Pb zircon data from the Sonsela Sandstone bed near the Sonsela Buttes, northeastern Arizona, USA, support the presence of a distributive fluvial system. Geosphere, 15:1128-1139. https://doi.org/10.1130/GES02004.1

Martz, J.W. and Parker, W.G. 2017. Revised formulation of the Late Triassic Land Vertebrate "Faunachrons" of western North America: Recommendations for codifying nascent systems of vertebrate biochronology, p. 39-125. In Zeigler, K.E. and Parker, W.G. (eds.), Terrestrial Depositional Systems: Deciphering Complexities Through Multiple Stratigraphic Methods. Elsevier, Amsterdam. https://doi.org/10.1016/C2014-0-01267-1

McGregor, J.H. 1906. The Phytosauria with especial reference to Mystriosuchus and Rhytidodon. Memoirs of the American Museum of Natural History, 9:29-101.

Mehl, M.G. 1913. Angistorhinus, a new genus of Phytosauria from the Trias of Wyoming. Journal of Geology, 21:186-191. https://doi.org/10.1086/622049

Mehl, M.G. 1928. The Phytosauria of the Wyoming Triassic. Denison University Bulletin, Journal of the Scientific Laboratories, 23:141-172. https://doi.org/10.1086/622217

Melstrom, K.M. 2017. The relationship between diet and tooth complexity in living dentigerous saurians. Journal of Morphology, 278:500-522. https://doi.org/10.1002/jmor.20645

Miller-Camp, J. 2016. Patterns in alligatorine evolution. Unpublished PhD Thesis. The University of lowa, lowa City, lowa, USA. https://doi.org/10.17077/etd.214bqxd

Owen, R. 1859. Palaeontology. Encyclopedia Britannica, 17:91-176.

Owocki, K. and Madzia, D. 2020. Predatory behaviour in mosasaurid squamates inferred from tooth microstructure and mineralogy. Cretaceous Research, 111:104430. https://doi.org/10.1016/j.cretres.2020.104430

Parker, W.G. and Martz, J.M. 2011. The Late Triassic (Norian) Adamanian-Revueltian tetrapod faunal transition in the Chinle Formation of Petrified Forest National Park, Arizona. Earth and Environmental Science Transactions of the Royal Society of Edinburgh, 101:231-260. https://doi.org/10.1017/S1755691011020020

Parrish, J.M. 1993. Phylogeny of the Crocodylotarsi, with reference to archosaurian and crurotarsan monophyly. Journal of Vertebrate Paleontology, 13:287-308. https://doi.org/10.1080/02724634.1993.10011511 
Ramezani, J., Hoke, G.D., Fastovsky, D.E., Bowring, S.A., Therrien, F., Dworkin, S.I., Atchley, S.C., and Nordt, L.C., 2011. High-precision U-Pb zircon geochronology of the Late Triassic Chinle Formation, Petrified Forest National Park (Arizona, USA): Temporal constraints on the early evolution of dinosaurs. GSA Bulletin, 123:2142-2159. https://doi.org/10.1130/B30433.1

Sander, P.M. 1999. The microstructure of reptilian tooth enamel: terminology, function, and phylogeny: Müncher Geowissenschafliche Abhandlungen Reihe A, 38:1-102.

Scheyer, T.M., Desojo, J.B., and Cerda, I.A. 2014. Bone histology of phytosaur, aetosaur, and other archosauriform osteoderms (Eureptilia, Archosauromorpha). The Anatomical Record, 297:240-260. https://doi.org/10.1002/ar.22849

Smith, J.B. 2005. Heterodonty in Tyrannosaurus rex: Implications for the taxonomic and systematic utility of theropod dentitions. Journal of Vertebrate Paleontology, 25:865-887. https://doi.org/10.1671/0272-4634(2005)025[0865:hitrif]2.0.co;2

Spielmann, J.A. and Lucas, S.G. 2012. Tetrapod fauna of the Upper Triassic Redona Formation east-central New Mexico: The characteristic assemblage of the Apachean land-vertebrate faunachron. New Mexico Museum of Natural History and Science Bulletin, 55:1-119.

Stocker, M.R. 2010. A new taxon of phytosaur (Archosauria: Pseudosuchia) from the Late Triassic (Norian) Sonsela Member (Chinle Formation) in Arizona, and a critical reevaluation of Leptosuchus Case, 1922. Palaeontology, 53:997-1022. https://doi.org/10.1111/j.1475-4983.2010.00983.x

Stocker, M.R. 2012. A new phytosaur (Archosauriformes, Phytosauria) from the Lot's Wife beds (Sonsela Member) within the Chinle Formation (Upper Triassic) of Petrified Forest National Park, Arizona. Journal of Vertebrate Paleontology, 32:573-586. https://doi.org/10.1080/02724634.2012.649815

Stocker, M.R. and Butler, R.J. 2013. Phytosauria, p. 91-117. In Nesbitt, S.J., Desojo, J.B., Irmis, R.B. (eds.), Anatomy, Phylogeny and Palaeobiology of Early Archosaurs and Their Kin. Geological Society, London, Special Publication 379. https://doi.org/10.1144/SP379.5

Stokosa, K. 2005. Enamel microstructure variation within the Theropoda, p. 163-178. In Carpenter, K. (ed.), The Carnivorous Dinosaurs. Indiana University Press, Indianapolis, 163178.

Tanner, L.H., Chapman, M.G., and Zeigler, K.E. 2003. Facies analysis and sedimentologic model for deposition of bone-bearing strata in the Upper Triassic Petrified Forest Formation at the Snyder quarry, northcentral New Mexico. New Mexico Museum of Natural History and Science Bulletin, 24:41-48.

Trendell, A.M., Atchley, S.C., and Nordt, L.C. 2013. Facies analysis of a probable large-fluvialfan depositional system: The Upper Triassic Chinle Formation at Petrified Forest National Park, Arizona, U.S.A. Journal of Sedimentary Research, 83:873-895. https://doi.org/10.2110/jsr.2013.55

Wang, C-C., Song, Y., Song, S-R., Ji, Q., Chiang, C-C., Meng, Q., Li, H., Hsiao, K., Lu, Y-C., Shew, B-Y., Huang, T., and Reisz, R.R. 2015. Evolution and function of dinosaur teeth at ultramicrostructural level revealed using synchrotron transmission X-ray microscopy. Scientific Reports, 5:15202. https://doi.org/10.1038/srep15202

Weinbaum, J.C. and Hungerbühler, A. 2007. A revision of Poposaurus gracilis (Archosauria: Suchia) based on two new specimens from the Late Triassic of the southwestern U.S.A. Paläontologische Zeitschrift, 81:131-145. https://doi.org/10.1007/bf02988388

Whiteside, J.H., Grogan, D.S., Olsen, P.E., and Kent, D.V. 2011. Climatically driven biogeographic provinces of Late Triassic tropical Pangea. Proceedings of the National Academy of Sciences, 108:8972-8977. https://doi.org/10.1073/pnas.1102473108

Whitney, M. R. and Sidor, C. A. 2019. Histological and developmental insights into the herbivorous dentition of tapinocephalid therapsids. PLoS ONE, 14:e0223860. https://doi.org/10.1371/journal.pone.0223860

Wintrich, T., Hagdorn, H., and Sander, P. M. 2017. An enigmatic marine reptile-the actual first record of Omphalosaurus in the Muschelkalk of the Germanic basin. Journal of Vertebrate Paleontology, 37:e1384739. https://doi.org/10.1080/02724634.2017.1384739

Zeigler, K.E., Lucas, S.G., and Heckert, A.B. 2002. A phytosaur skull from the Upper Triassic Snyder Quarry (Petrified Forest Formation, Chinle Group). New Mexico Museum of Natural History Bulletin, 21:171-178. 
Zeigler, K.E., Heckert, A.B., and Lucas, S.G. 2003a. The vertebrate fauna of the Upper Triassic (Revueltian) Snyder Quarry. New Mexico Museum of Natural History and Science Bulletin, 24:71-80.

Zeigler, K.E., Heckert, A.B., and Lucas, S.G. 2003b. Phytosaur (Archosauria: Parasuchidae) cranial and mandibular material from the Upper Triassic Snyder Quarry (Petrified Forest Formation, Chinle Group). New Mexico Museum of Natural History and Science Bulletin, 24:81-88.

Zeigler, K.E., Heckert, A.B., and Lucas, S.G. 2003c. An illustrated atlas of the phytosaur (Archosauria: Parasuchidae) postcrania from the Upper Triassic Snyder Quarry (Petrified Forest Formation, Chinle Group). New Mexico Museum of Natural History Bulletin, 24:89104.

Zeigler, K.E., Heckert, A.B., and Lucas, S.G. 2005. Taphonomic analysis of a fire-related Upper Triassic vertebrate fossil assemblage from North-Central New Mexico. New Mexico Geological Society, 56th Field Conference Guidebook, Geology of the Chama Basin, p. 341354. 